\title{
23
}

\section{Can Myrtaceae pollen of the Holocene from Bega Swamp (New South Wales, Australia) be compared with extant taxa?}

\author{
Andrew H. Thornhill \\ Botany and Zoology, Research School of Biology, Australian National University, Canberra, Australia \\ Andrew.Thornhill@anu.edu.au
}

\section{Introduction}

Bega Swamp (Figure 1) is a seldom disturbed restiad-shrub bog (Hope et al. 2000) located $50 \mathrm{~km}$ inland at the eastern side of the Southern Tablelands in Wadbilliga National Park, New South Wales (36 31' S, $149^{\circ} 30^{\prime} \mathrm{E}$ ) at an altitude of around $1080 \mathrm{~m}$ and with a mean annual rainfall of $800 \mathrm{~mm}$ to $1200 \mathrm{~mm}$ (Polach and Singh 1980). Rainfall is a limiting factor to plant growth in the region (Donders et al. 2007). It is thought that the swamp originated as a valley fill between Yankee Creek and Bemboka River (Polach and Singh 1980) and occupies an elongated north-south valley on a heavily forested granitic plateau (Hope et al. 2000). The site was selected by Dr Gurdhip Singh to represent montane southeastern Australia as it was a Holocene site with continuous sedimentation that would allow near annual resolution analysis as well as being surrounded by relatively undisturbed natural vegetation, providing the possibility of relating the modern pollen deposition to climatic conditions (Hope 1995).

The surrounding catchment area of Bega Swamp is predominantly a wet, tall, open sclerophyll forest, with dominant Eucalyptus tree species being E. fraxinoides, E. fastigata, $E$. radiata and $E$. dalrympleana, along with a rich shrub and herb understorey containing genera such as Epacris, Leptospermum, Asteraceae, Acaena, Ranunculus, Hydrocotyle, Plantago, Wahlenbergia, Gonocarpus, Blechnum and Pteridium (Green et al. 1988; Hope et al. 2000). The swamp area has a zone of E. pauciflora (snowgum) and E. rubida woodlands with a grassy shrubland suggesting that this is a frost hollow (Hope et al. 2000). Poa grasslands occur in the western area of the swamp, while the majority of it is thickly overgrown with Empodisma and Restio, with scattered aquatic sedges and ericaceous and myrtaceous shrubs (Hope et al. 2000). It was noted by Hope et al. (2000) that Leptospermum lanigerum would probably occupy parts of the swamp but had been partly removed by fire. 


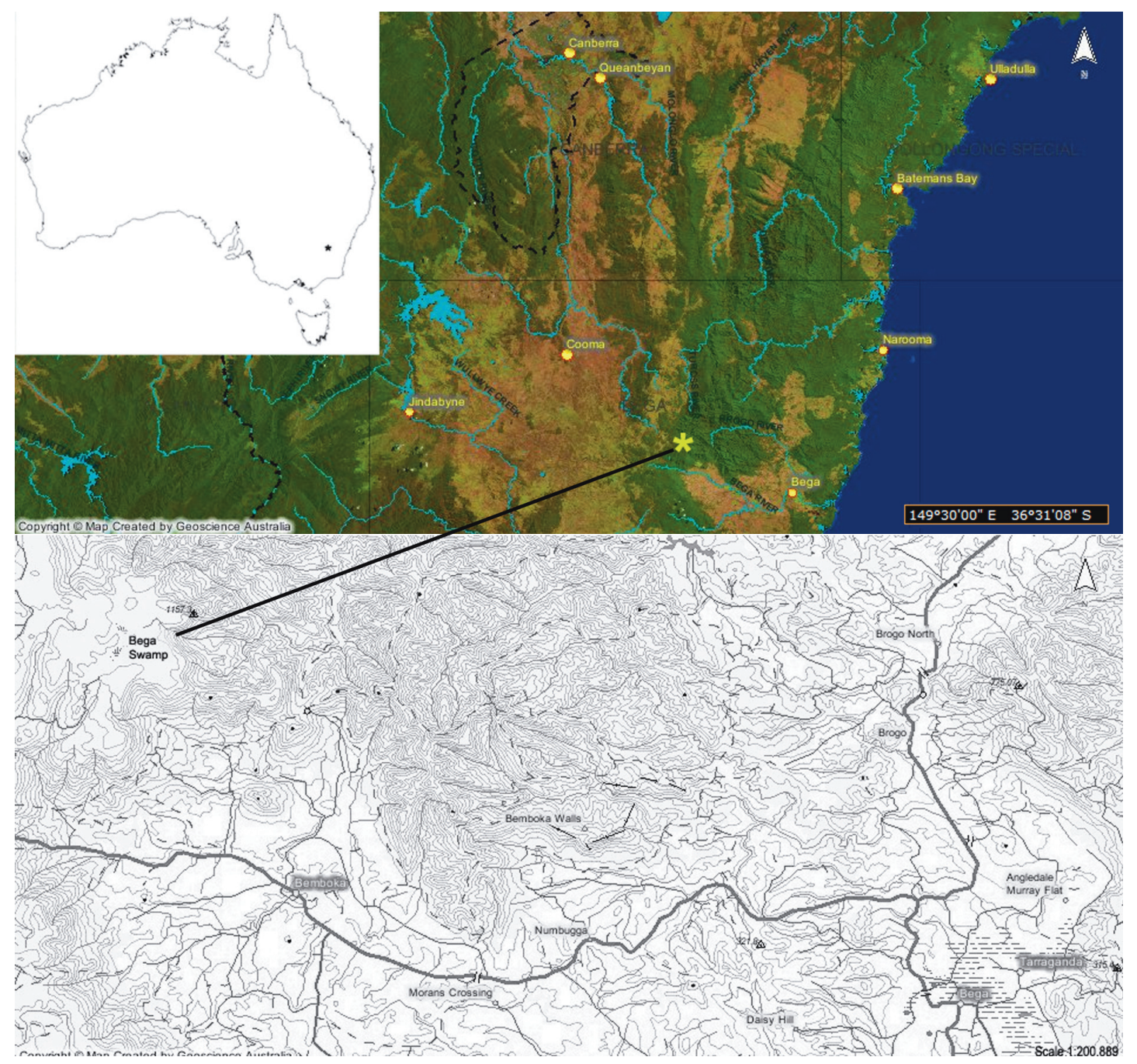

Figure 1. Locality map of Bega Swamp

Detailed pollen counts from the past 12,000 years have previously been conducted (Green et al. 1988; Hope 1995; Hope et al. 2000, 2004; Donders et al. 2007), from which 35 Myrtaceae-type pollen grains have been identified (Hope et al. 2000), with these various pollen types appearing at different times (Figure 2). Interestingly, the number of recorded Myrtaceae species housed at the Australian National Herbarium that come from the Wadbilliga National Park region is 37 (see Table 1 for species list). Various assumptions have been made about the identities of the pollen types, first by Gurdhip Singh (unpublished data) and then by Geoff Hope (Figure 2). One notable assumption is that E. pauciflora was a dominant eucalypt in the past, associated with a cooler and wetter climate at Bega Swamp. This is illustrated in Figure 2, which distinguishes five groups of Eucalyptus appearing and disappearing through the past 12,000 years. It was assumed that Eucalyptus 2 represented a high altitude group such as E. pauciflora, while Eucalyptus 3 and 4 were wet forest groups such as E. fastigata and E. fraxinoides (Hope 1995). The present study examined extant Myrtaceae taxa from the Bega Swamp area with light microscopy and compared images of Myrtaceae pollen grains from various sections of Singh's 1980 core using visual character comparison and a Lucid key of extant Myrtaceae pollen morphology (Thornhill unpublished) with the aim of correlating extant and fossil pollen. 


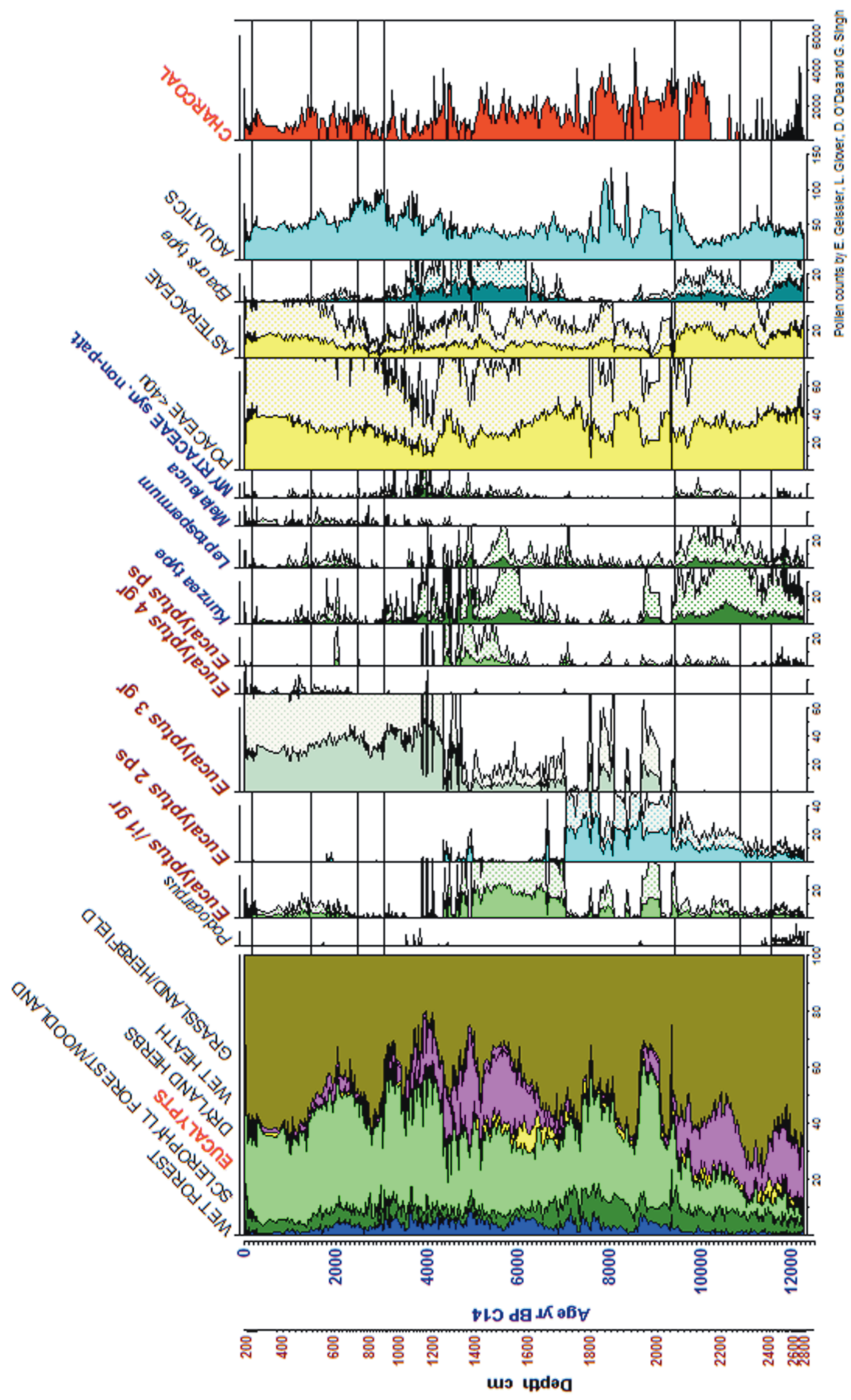

Figure 2a. Pollen diagrams from a 1980 core of Bega Swamp showing various plant families and genera found in the core 


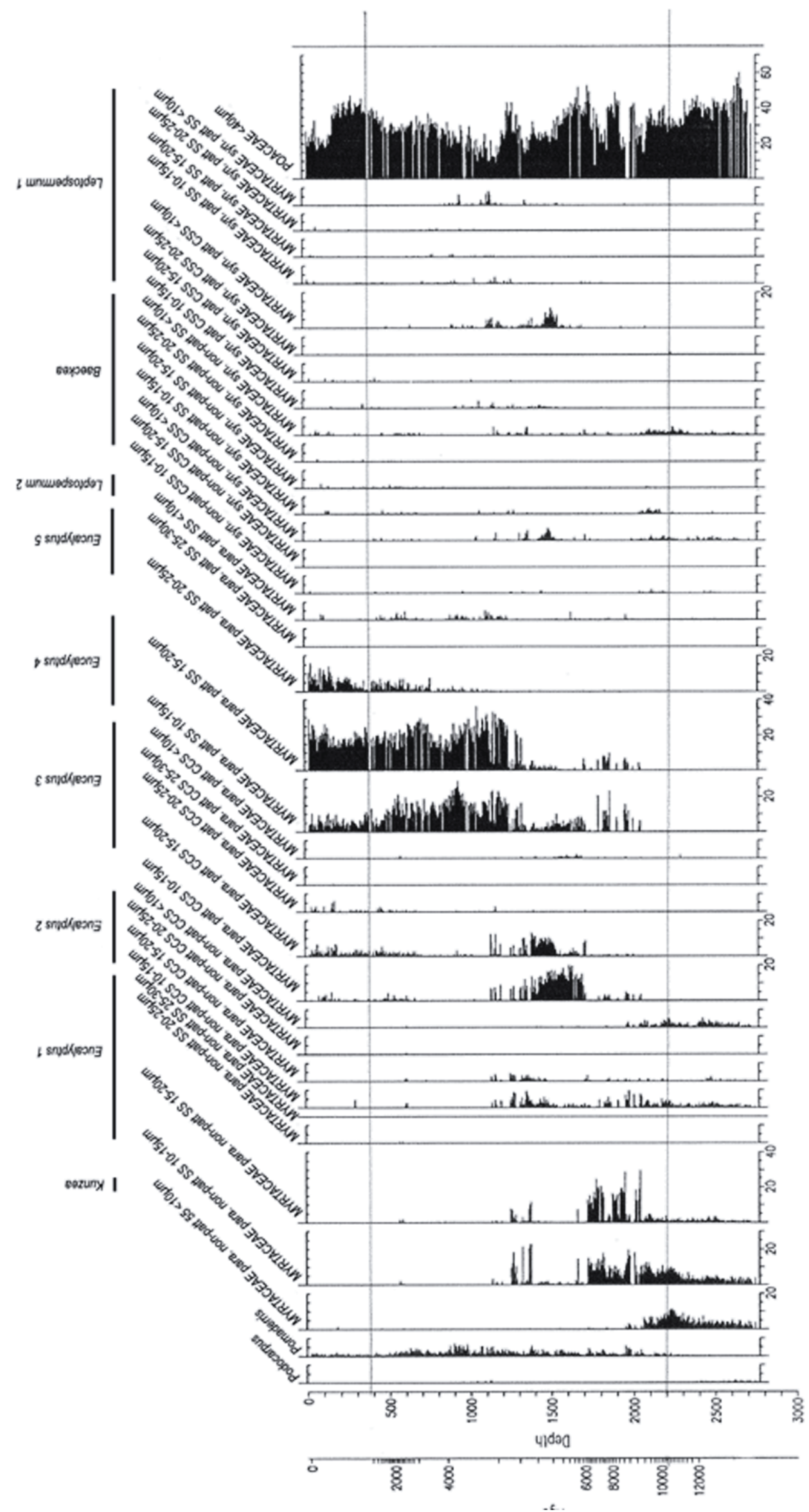

Figure 2b. Pollen diagrams from a 1980 core of Bega Swamp showing the presence of 35 Myrtaceae pollen grains and how they were grouped by Hope et al. in 2000 
Table 1. Species list of Myrtaceae taxa from the area surrounding Bega Swamp (Table 1 continues on page 410)

\begin{tabular}{|c|c|c|c|}
\hline Myrtaceae taxa & $\begin{array}{l}\text { Taxa from Wadbilliga } \\
\text { National Park recorded } \\
\text { in Australian herbaria }\end{array}$ & $\begin{array}{l}\text { Other taxa listed to } \\
\text { occur in the area }\end{array}$ & $\begin{array}{l}\text { Taxa that Gurdhip } \\
\text { Singh suggested } \\
\text { resembled fossil pollen }\end{array}$ \\
\hline $\begin{array}{l}\text { Acmena smithii (Poir.) Merr. \& } \\
\text { L.M.Perry }\end{array}$ & $\mathrm{x}$ & & \\
\hline Angophora floribunda (Sm.) Sweet & & & $\mathrm{x}$ \\
\hline $\begin{array}{l}\text { Babingtonia pluriflora (F.Muell.) } \\
\text { A.R.Bean ex Govaerts \& al. }\end{array}$ & & $\mathrm{x}$ & \\
\hline Backhousia myrtifolia Hook. \& Harv. & $\mathrm{x}$ & & \\
\hline $\begin{array}{l}\text { Baeckea gunniana Schauer ex Walp., } \\
\text { Repert }\end{array}$ & & & $\mathrm{x}$ \\
\hline Baeckea linifolia Rudge & & $\mathrm{x}$ & \\
\hline Baeckea utilis F.Muell. ex Miq. & $\mathrm{x}$ & & \\
\hline $\begin{array}{l}\text { Baeckea virgata (J.R.Forst. \& G.Forst.) } \\
\text { Andrews (now Sannantha) }\end{array}$ & & $\mathrm{x}$ & \\
\hline Callistemon citrinus (Curtis) Skeels & & $\mathrm{x}$ & \\
\hline $\begin{array}{l}\text { Callistemon salignus (Sm.) Colv. ex } \\
\text { Sweet }\end{array}$ & & $\mathrm{x}$ & \\
\hline Callistemon sieberi $\mathrm{DC}$. & $\mathrm{x}$ & & \\
\hline Callistemon subulatus Cheel & & $\mathrm{x}$ & \\
\hline Calytrix tetragona Labill. & & $\mathrm{x}$ & \\
\hline $\begin{array}{l}\text { Corymbia gummifera (Gaertn.) } \\
\text { K.D.Hill \& L.A.S.Johnson }\end{array}$ & & $\mathrm{x}$ & \\
\hline $\begin{array}{l}\text { Corymbia maculata (Hook.) K.D.Hill } \\
\& \text { L.A.S.Johnson }\end{array}$ & & $\mathrm{x}$ & \\
\hline $\begin{array}{l}\text { Eucalyptus badjensis Beuzev. \& } \\
\text { M.B.Welch }\end{array}$ & $\mathrm{x}$ & & \\
\hline Eucalyptus baeuerlenii F.Muell. & $\mathrm{x}$ & & \\
\hline Eucalyptus dalrympleana Maiden & $\mathrm{x}$ & & \\
\hline Eucalyptus elata Dehnh. & $\mathrm{x}$ & & \\
\hline $\begin{array}{l}\text { Eucalyptus fastigata H.Deane \& } \\
\text { Maiden }\end{array}$ & & & $\mathrm{x}$ \\
\hline $\begin{array}{l}\text { Eucalyptus fraxinoides H.Deane \& } \\
\text { Maiden }\end{array}$ & $\mathrm{x}$ & & $\mathrm{x}$ \\
\hline $\begin{array}{l}\text { Eucalyptus kybeanensis Maiden } \& \\
\text { Cambage }\end{array}$ & $\mathrm{x}$ & & \\
\hline $\begin{array}{l}\text { Eucalyptus moorei Maiden \& } \\
\text { Cambage subsp. moorei }\end{array}$ & $\mathrm{x}$ & & \\
\hline $\begin{array}{l}\text { Eucalyptus nitens (H.Deane \& } \\
\text { Maiden) Maiden }\end{array}$ & $\mathrm{x}$ & & \\
\hline $\begin{array}{l}\text { Eucalyptus olsenii L.A.S.Johnson \& } \\
\text { Blaxell }\end{array}$ & $\mathrm{x}$ & & \\
\hline $\begin{array}{l}\text { Eucalyptus paliformis L.A.S.Johnson } \\
\& \text { Blaxell }\end{array}$ & $\mathrm{x}$ & & \\
\hline $\begin{array}{l}\text { Eucalyptus parvula L.A.S.Johnson \& } \\
\text { K.D.Hill }\end{array}$ & $\mathrm{x}$ & & \\
\hline Eucalyptus pauciflora Sieber ex Spreng. & $\mathrm{x}$ & & $\mathrm{x}$ \\
\hline $\begin{array}{l}\text { Eucalyptus radiata Sieber ex DC. } \\
\text { subsp. radiata }\end{array}$ & $\mathrm{x}$ & & \\
\hline Eucalyptus smithii R.T.Baker & $\mathrm{x}$ & & \\
\hline Eucalyptus stellulata Sieber ex DC. & $\mathrm{x}$ & & $\mathrm{x}$ \\
\hline
\end{tabular}




\begin{tabular}{|c|c|c|c|}
\hline Myrtaceae taxa & $\begin{array}{l}\text { Taxa from Wadbilliga } \\
\text { National Park recorded } \\
\text { in Australian herbaria }\end{array}$ & $\begin{array}{l}\text { Other taxa listed to } \\
\text { occur in the area }\end{array}$ & $\begin{array}{l}\text { Taxa that Gurdhip } \\
\text { Singh suggested } \\
\text { resembled fossil pollen }\end{array}$ \\
\hline $\begin{array}{l}\text { Eucalyptus stenostoma L.A.S.Johnson } \\
\& \text { Blaxell }\end{array}$ & $\mathrm{x}$ & & \\
\hline Eucalyptus viminalis Labill. & & & $\mathrm{x}$ \\
\hline Eucalyptus wilcoxii Boland \& Kleinig & $\mathrm{x}$ & & \\
\hline $\begin{array}{l}\text { Euryomyrtus denticulata (Maiden \& } \\
\text { Betche) Trudgen }\end{array}$ & $\mathrm{x}$ & & \\
\hline Kunzea ambigua (Sm.) Druce & & $\mathrm{x}$ & \\
\hline $\begin{array}{l}\text { Kunzea ericoides (A.Rich.) Joy } \\
\text { Thomps. }\end{array}$ & & $\mathrm{x}$ & \\
\hline Kunzea parvifolia Schauer & & $\mathrm{x}$ & \\
\hline Kunzea sp. 'Wadbilliga' (Rodd 6168) & $\mathrm{x}$ & & \\
\hline Leptospermum brevipes F.Muell. & $\mathrm{x}$ & & \\
\hline Leptospermum grandifolium Sm. & $\mathrm{x}$ & & \\
\hline Leptospermum morrisonii Joy Thomps. & $\mathrm{x}$ & & \\
\hline $\begin{array}{l}\text { Leptospermum myrtifolium Sieber ex } \\
\text { DC. }\end{array}$ & $\mathrm{x}$ & & $\mathrm{x}$ \\
\hline Leptospermum obovatum Sweet & $\mathrm{x}$ & & \\
\hline $\begin{array}{l}\text { Leptospermum polygalifolium Salisb. } \\
\text { subsp. polygalifolium }\end{array}$ & $\mathrm{x}$ & & \\
\hline $\begin{array}{l}\text { Leptospermum scoparium J.R.Forst. \& } \\
\text { G.Forst. }\end{array}$ & & & $\mathrm{x}$ \\
\hline $\begin{array}{l}\text { Melaleuca armillaris (Sol. ex Gaertn.) } \\
\text { Sm. subsp. armillaris }\end{array}$ & $\mathrm{x}$ & & \\
\hline $\begin{array}{l}\text { Melaleuca citrina (Curtis) Dum. } \\
\text { Cours. }\end{array}$ & $\mathrm{x}$ & & \\
\hline Melaleuca hypericifolia Sm. & $\mathrm{x}$ & & \\
\hline Melaleuca pityoides (F.Muell.) Craven & $\mathrm{x}$ & & \\
\hline Melaleuca subulata (Cheel) Craven & $\mathrm{x}$ & & \\
\hline $\begin{array}{l}\text { Tristania neriifolia (Sieber ex Sims) } \\
\text { R.Br. }\end{array}$ & & & $\mathrm{x}$ \\
\hline $\begin{array}{l}\text { Tristaniopsis laurina (Sm.) Peter } \\
\text { G.Wilson \& J.T.Waterh. }\end{array}$ & $\mathrm{x}$ & & $\mathrm{x}$ \\
\hline
\end{tabular}

Pollen of the plant family Myrtaceae is characterised by a syncolpate or parasyncolpate appearance, although some Myrtaceae tribes are brevicolpate and asyncolpate (Thornhill unpublished data), with many studies conducted on the pollen of the family or specific groups within (Pike 1956; McIntyre 1963; Churchill 1968; Barth and Barbosa 1973; Graham 1980; Gadek and Martin 1981; Gadek and Martin 1982; Patel et al. 1984; Van Wyk and Dedekind 1985; Martin and Gadek 1988; Chalson and Martin 1995; Pickett and Newsome 1997; Parnell 2003; Eliseu and Dinis 2008). It has been said that at the generic and species levels, separation of taxa can be difficult or impossible (Pickett and Newsome 1997), but a number of useful and distinctive characters have been created to tackle the task (Dodson 1974; Chalson and Martin 1995). The high significance that is placed on Myrtaceae, especially Eucalyptus, when identifying pollen to interpret past vegetation and climatic conditions means that the ability to differentiate Myrtaceae into distinct pollen groups is of great value. Most important, as Pickett and Newsome (1997) noted, is whether Eucalyptus pollen might be identifiable to species, or groups of species. 


\section{Methods}

As many extant Myrtaceae genera and species as were readily available were imaged with light microscopy. Images were taken from existing slides sourced from the pollen slide collection in the Department of Archaeology and Natural History (ANH), Australian National University, and from slides made by Kathleen Pike in the 1940s and '50s (many of which are line illustrated in Pike 1956) housed at the School of Botany, University of Melbourne, and the School of Land and Environment, University of Melbourne. Taxa used for extant reference pollen were selected by searching a species list of Wadbilliga National Park housed in the Australian National Herbarium, Canberra, and from a Bega Swamp species list compiled by Gurdhip Singh (unpublished). New slides were created for the Bega Swamp fossil pollen from archived residues, as the slides used in previous studies had been lost. The original core was taken in 1980 by Gurdhip Singh who froze the core on site and then sliced it with a fine bandsaw into a series of 500 discs of $20 \mathrm{~cm}$ diameter and approximately $2.5 \mathrm{~mm}$ thickness, resulting in a sample every $4 \mathrm{~mm}$ (Hope 1995). The archived acetolysed samples are stored in silicone oil at ANH. Peaks in concentration of fossil Myrtaceae pollen grains were recognised from the pollen diagram (Figure 2), and from these peaks archived samples were selected for the new slides. The chronology used in this study comes from several previous published studies (Hope et al. 2000; Wheeler et al. 2001), as well as unpublished dates provided by Dr Nick Porch from ANH. This chronology is summarised in Table 2 and it is worth noting that the chronology is now the highest resolution sequence in Australia. Specimens for new slides were mounted in silicone oil and all images were captured using a Zeiss (Oberkochen) Microscope, objective lens x63 and the image capturing software Axiovision.

Table 2. Depth and age of core sample numbers

\begin{tabular}{|l|l|l|}
\hline Sample number & Depth $(\mathbf{m m})$ & Age \\
\hline $54,55,56$ & $302-316$ & -400 years \\
\hline $81,82,83$ & $400-419$ & 850 years \\
\hline $115,116,117,118$ & $583-606$ & 2300 years \\
\hline 194,195 & $980-1002$ & 3400 years \\
\hline 202 & $1006-1009$ & 3500 years \\
\hline $238,239,240$ & $1197-1213$ & 4300 years \\
\hline $269,270,271$ & $1369-1386$ & 4700 years \\
\hline 274 & $1399-1404$ & 4800 years \\
\hline 290,291 & $1494-1505$ & 5000 years \\
\hline $344,345,346$ & $1796-1814$ & 8500 years \\
\hline 374 & $1971-1975$ & 8800 years \\
\hline $440,441,442$ & $2199-2213$ & 10,900 years \\
\hline $498,499,500$ & $2497-2511$ & 12,500 years \\
\hline
\end{tabular}

Both extant and fossil pollen grains were scored using the characters described by Chalson and Martin (1995) and descriptions followed the terminology of Punt et al. (2007). Pollen measurements were also made in Adobe Photoshop. A Lucid key was created compiling character scores of extant Myrtaceae pollen. The key, which contains 329 Myrtaceae taxa that have been imaged with light microscopy (and another 220 with scanning electron microscopy), was then used to search for similarities with the fossil pollen by entering the characters of each individual fossil pollen grain (more than 400 grains in total). 


\section{Results}

\section{Extant Myrtaceae}

In total, 25 Myrtaceae taxa representing 10 genera were used as a reference for extant pollen, and in most instances, pollen grains could be sorted down to a species level using a total of 15 morphological characters and image measurements (Figure 3).
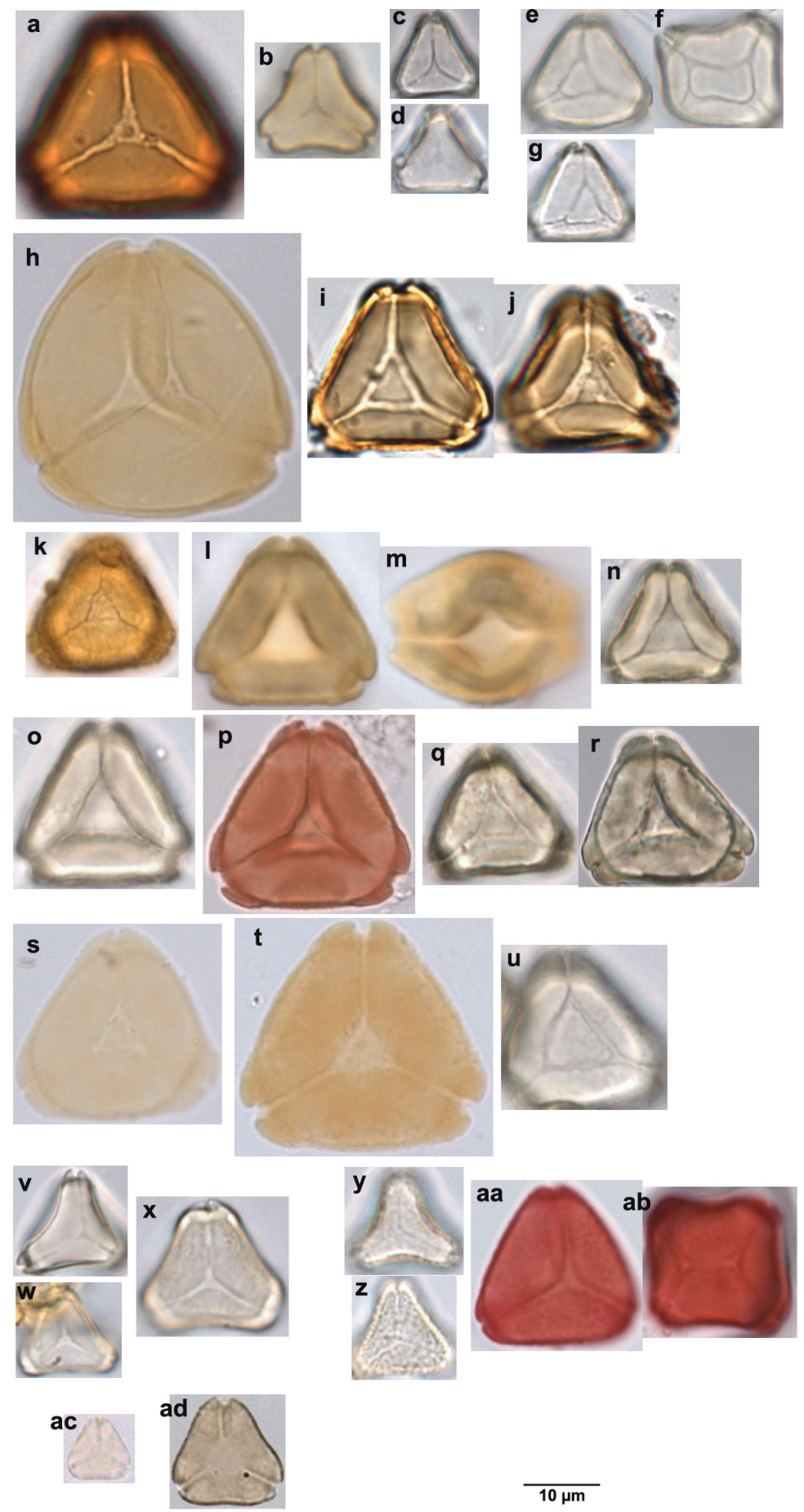

Figure 3. Extant Myrtaceae pollen of Bega Swamp (a) Angophora floribunda; (b) Backhousia myrtifolia; (c) Baeckea gunniana; (d) Baeckea utilis; (e) and (f) Callistemon citrinus; (g) Callistemon sieberi; (h) Corymbia gummifera; (i) and (j) Corymbia maculata; (k) Eucalyptus dalrympleana; (I) and (m) E. fastigata; (n) E. fraxinoides; (0) E. pauciflora; (p) E. radiata; (q) and (г) E. rubida; (s) E. smithii; (t) E. stellulata; (u) E. viminalis; (v) Kunzea ambigua; (w) K. ericoides; (x) K. parvifolia; (y) Leptospermum grandifolium; (z) L. lanigerum; (aa) and (ab) L. scoparium; (ac) Tristania neriifolia; (ad) Tristaniopsis laurina Scale bar $-10 \mu \mathrm{m}$ 


\section{Eucalyptus and allies}

Nine Eucalyptus species (Figure $3 \mathrm{k}-\mathrm{u}$ ) were sampled, representing five eucalypt groups: peppermints (E. radiata), longitudinale (E. stellulata), symphomyrtus (E. smithii, E. viminalis, E. rubida and $E$. dalrympleana), snowgum (E. pauciflora) and ashes (E. fastigata and E. fraxinoides), showing a variation in pollen length among species $(16-25.7 \mu \mathrm{m})$. Eucalyptus pauciflora and E. fraxinoides exhibited pollen grains which were parasyncolpate with straight sides and had psilate/scabrate exine patterning, with $E$. pauciflora appearing slightly larger on average $(20.4 \mu \mathrm{m}$ compared with $16 \mu \mathrm{m})$. Eucalyptus fastigata was also straight sided, but had psilate exine patterning. Eucalyptus rubida showed presence of an apocolpial island, as did E. viminalis. Eucalyptus dalrympleana had scabrate exine patterning, while E. stellulata was large in size with convex pollen sides and psilate/scabrate patterning. The pollen grains of genera Angophora and Corymbia (Figure $3 \mathrm{a}, \mathrm{h}-\mathrm{j}$ ), which are in the same Myrtaceae tribe as Eucalyptus, could be distinguished by their larger size (pollen length of 18-34 $\mu \mathrm{m}$ ) and arcuate-shaped colpi. The majority of Angophora and Corymbia also had apocolpial islands present.

\section{Other Myrtaceae}

Nine other Myrtaceae genera were used as reference pollen. Grains of Callistemon (now Melaleuca) were parasyncolpate with straight edges and a large closely fitting island present and had a pollen length range of 12-15.6 $\mu \mathrm{m}$ (Figure $3 \mathrm{e}-\mathrm{g}$ ). The majority of other Myrtaceae genera exhibited small pollen grains (pollen length $<15 \mu \mathrm{m}$ ). Kunzea and Leptospermum, which are both in the Leptospermeae tribe, had syncolpate grains with straight or concave edges and arcuate colpi, the difference being that Leptospermum pollen had granulate/scabrate exine patterning while Kunzea was psilate (Figure $3 \mathrm{v}$-ab). Baeckea pollen (Figure $3 \mathrm{c}$ and d) was also syncolpate with arcuate colpi making it difficult to separate from Kunzea pollen, the most notable difference being that Kunzea were less syncolpate than Baeckea. Backhousia myrtifolia (Figure $3 \mathrm{~b}$ ) and Tristaniopsis laurina pollen (Figure $3 \mathrm{ad}$ ) looked similar, both being parasyncolpate with concave sides, while pollen from Tristania neriifolia (Figure $3 \mathrm{ac}$ ) was extremely small, on average being less than $8 \mu \mathrm{m}$ in length.

\section{Fossil Myrtaceae}

A total of 428 Myrtaceae pollen grains was recognised from the 32 core sections sampled. Comparison of the fossil pollen with extant specimens showed trends in the genera and species that were present at Bega Swamp at various times (Table 3). Eucalyptus pollen grains were found in every sample examined but the total number of eucalypt grains per sample, as well as the number of eucalypt 'species' identified per sample, varied through time. The results given by entering pollen characters into the Lucid key and by simply looking at the grains were compared and found to be compatible. Sixty-nine (16\%) Lucid key suggestions did not match visual assumptions. Three-hundred-and-fifty-nine (84\%) Lucid suggestions matched to at least genera visual judgements; of these, 119 (28\%) Lucid suggestions gave matching species.

\section{Core samples 54-56, depth 302-316 mm, age $-400 \mathrm{BP}$}

52 grains, 8 unmatched between Lucid and visual, 34 generically matched, 10 fully matched.

The youngest core samples investigated, approximately 400 years old, presented a variety of pollen types, the most dominant being similar to E. rubida (Figure $4 \mathrm{~h}$ ) and E. pauciflora (Figure $4 \mathrm{a}, \mathrm{g}$ and $\mathrm{j}$ ). Seven other Eucalyptus pollen types were identified in smaller numbers. One diporate grain (Figure $4 \mathrm{~d}$ ) was found and attributed to E. fastigata, although it is possible that other Eucalyptus species have diporate pollen grains. Pollen thought to belong to Callistemon (Figure $4 \mathrm{~m}$ ) was present, as were Kunzea (Figure 4 i), Tristania (Figure $4 \mathrm{n}$ ), Baeckea (Figure 4 i) and Leptospermum. 
Table 3. Grain numbers of various core sections attributed to Myrtaceous pollen types using visual judgement

\begin{tabular}{|c|c|c|c|c|c|c|c|c|c|c|c|c|c|}
\hline \multirow[b]{2}{*}{ Genus } & \multicolumn{13}{|c|}{ Core sample numbers } \\
\hline & $\begin{array}{l}54- \\
56\end{array}$ & $\begin{array}{l}81- \\
83\end{array}$ & $\begin{array}{l}115- \\
118\end{array}$ & $\begin{array}{l}194- \\
195\end{array}$ & 202 & $\begin{array}{l}238- \\
240\end{array}$ & $\begin{array}{l}269- \\
271\end{array}$ & 274 & $\begin{array}{l}290- \\
291\end{array}$ & $\begin{array}{l}344- \\
346\end{array}$ & 374 & $\begin{array}{l}440- \\
442\end{array}$ & $\begin{array}{l}498- \\
500\end{array}$ \\
\hline Eucalyptus fraxinoides & 3 & 2 & 11 & 4 & 0 & 11 & 14 & 5 & 5 & 5 & 0 & 5 & 3 \\
\hline Eucalyptus pauciflora & 8 & 0 & 8 & 2 & 0 & 2 & 7 & 1 & 5 & 7 & 1 & 10 & 7 \\
\hline Eucalyptus fastigata & 4 & 4 & 9 & 0 & 1 & 3 & 6 & 1 & 6 & 5 & 1 & 1 & 7 \\
\hline Eucalyptus rubida & 14 & 3 & 12 & 3 & 0 & 5 & 6 & 2 & 6 & 1 & 1 & 4 & 3 \\
\hline $\begin{array}{l}\text { Eucalyptus } \\
\text { dalrympleana }\end{array}$ & 2 & 2 & 3 & 0 & 0 & 1 & 3 & 1 & 1 & 0 & 0 & 1 & 0 \\
\hline Eucalyptus viminalis & 6 & 1 & 2 & 0 & 0 & 1 & 1 & 1 & 0 & 2 & 0 & 2 & 1 \\
\hline Eucalyptus smithii & 1 & 2 & 5 & 1 & 0 & 2 & 2 & 0 & 0 & 0 & 0 & 0 & 1 \\
\hline Eucalyptus radiata & 1 & 0 & 0 & 0 & 0 & 0 & 0 & 0 & 0 & 0 & 0 & 0 & \\
\hline Eucalyptus stellulata & 1 & 1 & 2 & 1 & 0 & 1 & 2 & 0 & 0 & 1 & 0 & 0 & 1 \\
\hline Angophora/Corymbia & 0 & 0 & 2 & 0 & 0 & 0 & 0 & 0 & 0 & 0 & 0 & 0 & 0 \\
\hline Callistemon & 7 & 1 & 3 & 1 & 1 & 2 & 6 & 0 & 0 & 0 & 1 & 1 & 1 \\
\hline Kunzea & 4 & 1 & 6 & 0 & 1 & 5 & 9 & 2 & 15 & 0 & 3 & 1 & 3 \\
\hline Leptospermum & 1 & 0 & 1 & 0 & 0 & 6 & 8 & 1 & 1 & 0 & 2 & 1 & 1 \\
\hline Baeckea & 1 & 0 & 5 & 1 & 1 & 5 & 6 & 1 & 8 & 0 & 1 & 1 & 3 \\
\hline Tristania neriifolia & 1 & 1 & 2 & 0 & 0 & 2 & 1 & 0 & 1 & 0 & 0 & 0 & 1 \\
\hline Tristaniopsis laurina & 0 & 0 & 1 & 0 & 0 & 1 & 0 & 0 & 0 & 0 & 0 & 0 & 0 \\
\hline
\end{tabular}

Core samples 81-83, depth 400-419 mm, age $850 \mathrm{BP}$

22 grains, 2 unmatched, 16 generically matched, 4 fully matched.

Seven Eucalyptus pollen grains were identified but no species appeared dominant and grains from E. pauciflora were not seen. One pollen grain from an Angophora or Corymbia (Figure $4 \mathrm{t}$ ) was observed, as well as grains from Callistemon (Figure 4 v), Kunzea (Figure 4 w) and Tristania (Figure $4 \mathrm{~s}$, overleaf).

\section{Core samples 115-118, depth 583-606 mm, age $2300 \mathrm{BP}$}

74 grains, 9 unmatched, 43 generically matched, 22 fully matched.

Eucalyptus rubida (Figure 5 o, overleaf), E. fraxinoides (Figure $5 \mathrm{c}, \mathrm{di}, \mathrm{s}$ and t), E. fastigata (Figure $5 \mathrm{~h}$ ) and E. pauciflora (Figure $5 \mathrm{k}$ and $\mathrm{n}$ ) all had many grains attributed to them during this time period. Another four Eucalyptus species had pollen grains attributed to them and grains from Angophora or Corymbia (Figure 5 q) were identified. Kunzea and/or Baeckea pollen grains (Figure $5 \mathrm{f}, \mathrm{p}$ and $\mathrm{u}$ ) showed an increased number, while grains from Tristania, Leptospermum and Tristaniopsis were found. 


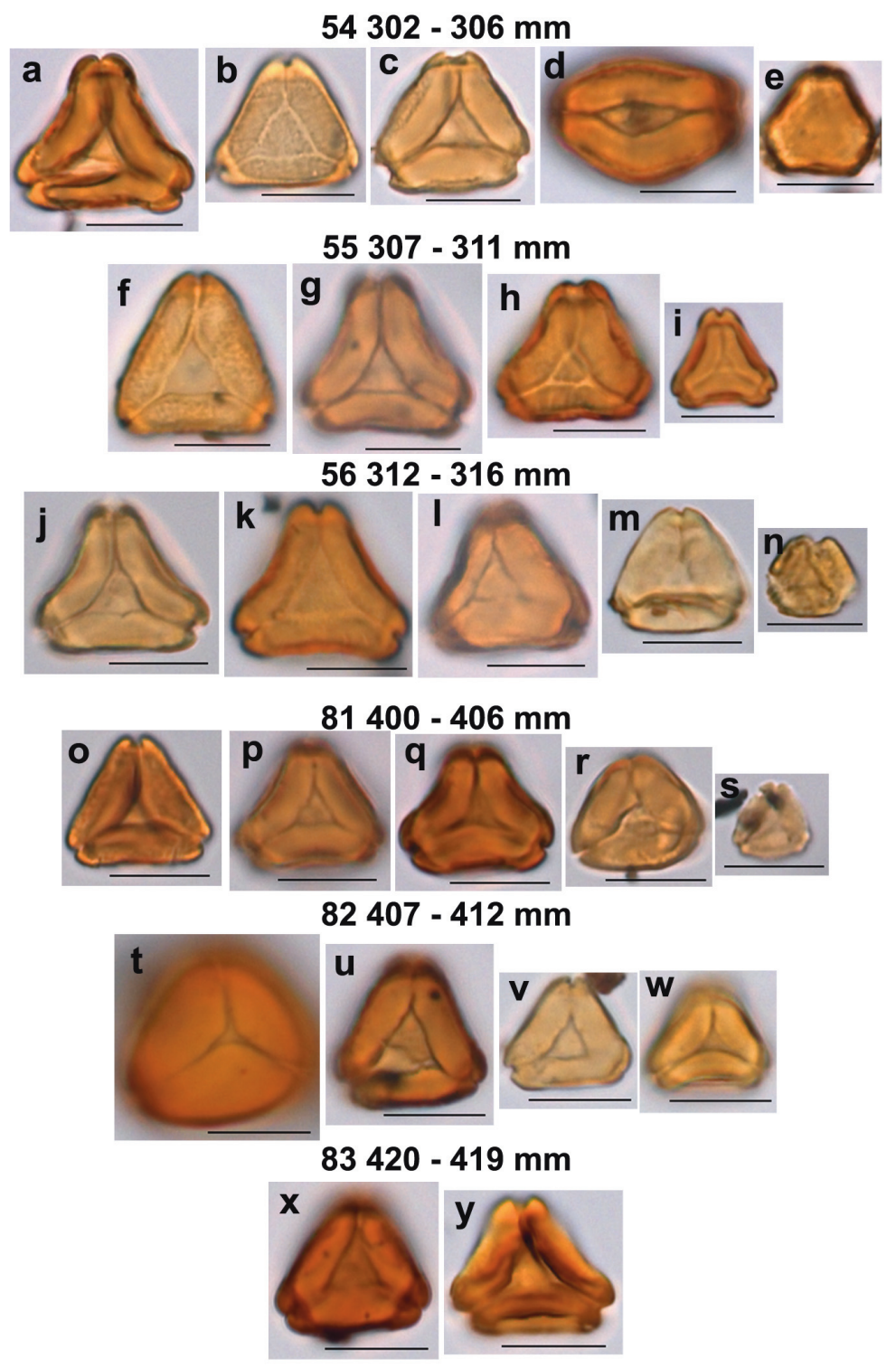

Figure 4. Examples of fossil pollen types from Bega Swamp core sections 54-56 and 81-83 with related core depth. 54 (a) E. pauciflora; (b); (c) E. fastigata; (d) Diporate E. fastigata; (e) Kunzea; 55 (f) E. viminalis; (g) E. pauciflora; (h) E. rubida; (i) Baeckea; 56 (j) E. pauciflora; (k) E. fastigata; (I) E. rubida; (m) Callistemon; (n) Tristania; 81 (0) E. fraxinoides; (p) E. dalrympleana; (q) E. pauciflora; (г) E. rubida; (s) Tristania; 82 (t) Angophora/Corymbia; (u) E. viminalis; (v) Callistemon; (w) Kunzea; 83 (x) E. smithii; (y) E. fastigata

Scale bar $-10 \mu \mathrm{m}$ 

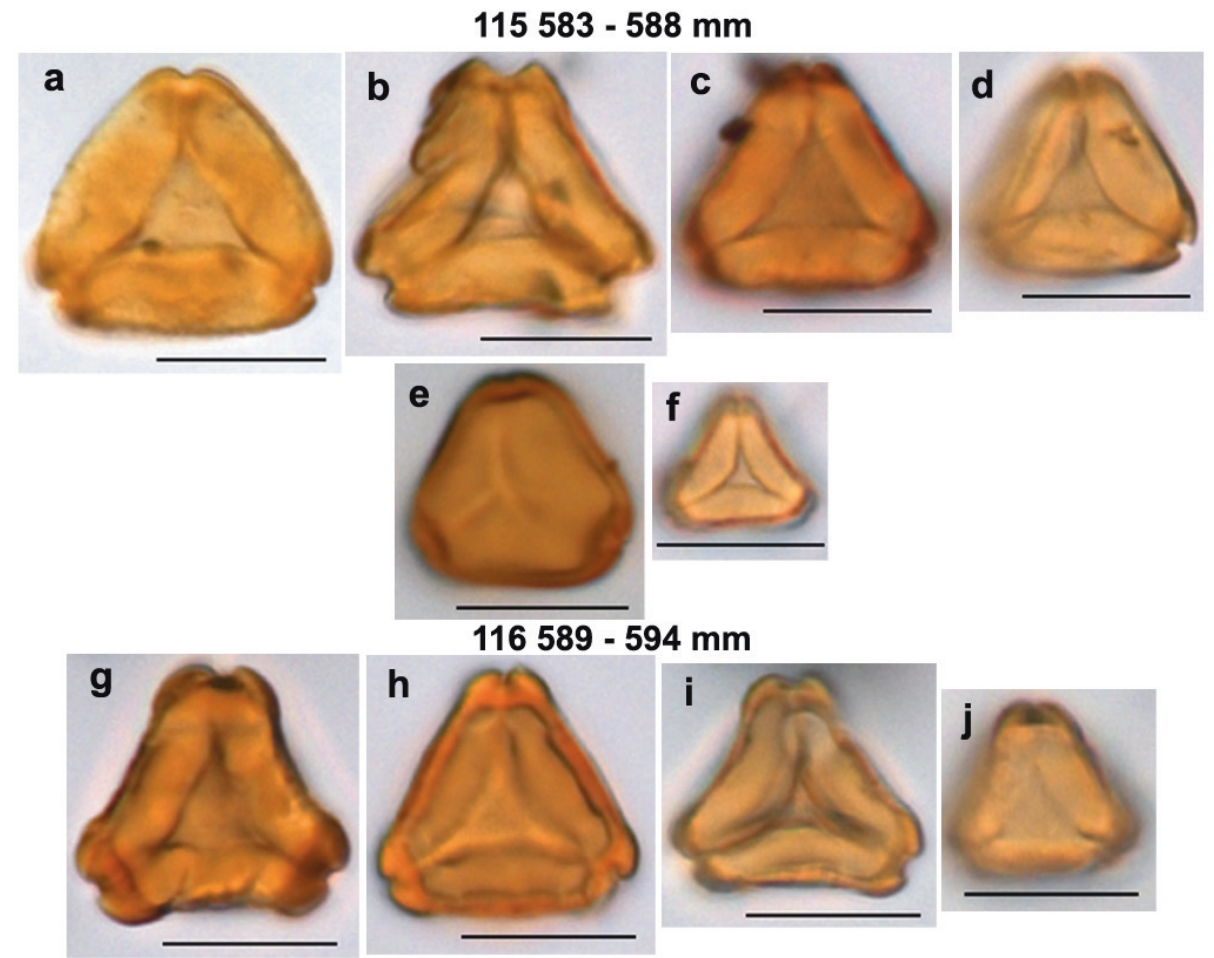

$117595-600 \mathrm{~mm}$
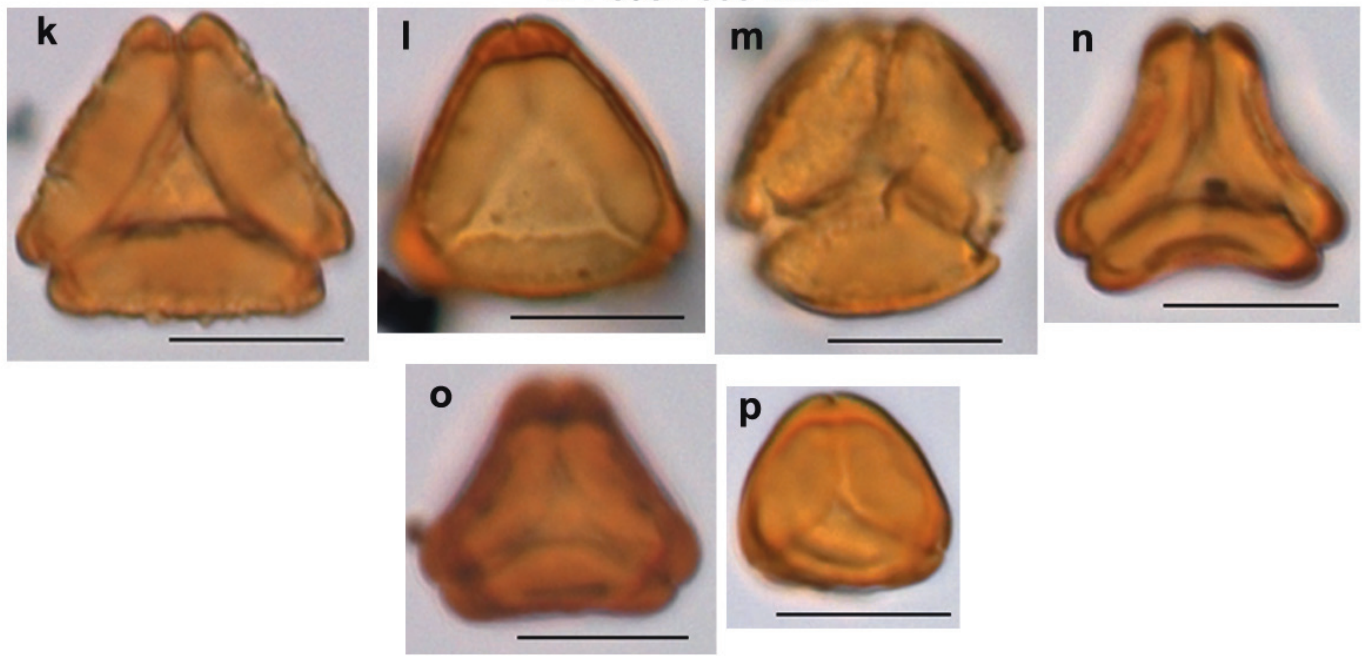

$118601-606 \mathrm{~mm}$
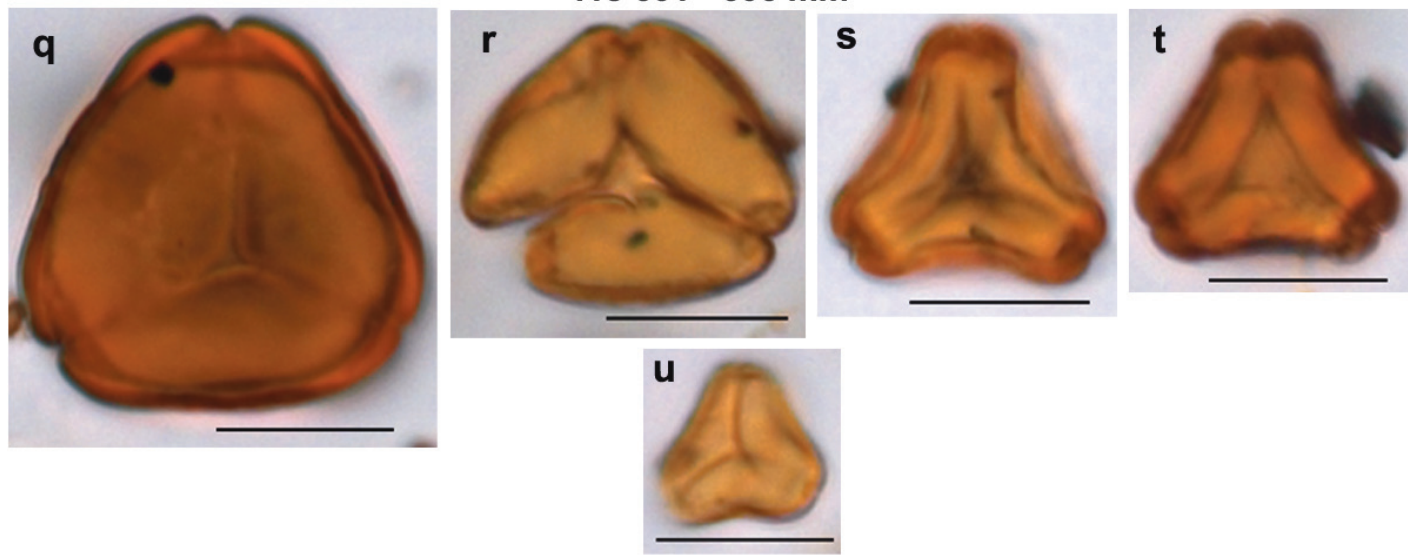

Figure 5. Examples of fossil pollen from Bega Swamp core sections 115-118 with related core depth. 115 (a) E. stellulata; (b) E. pauciflora; (c) and (d) E. fraxinoides; (e) Kunzea; (f) Baeckea; 116 (g) E. pauciflora; (h) E. fastigata; (i) E. fraxinoides; (j) Callistemon; 117 (k) E. pauciflora; (I) E. viminalis; (m) Angophora/Corymbia; (n) E. pauciflora; (0) E. rubida; (p) Kunzea/Baeckea; 118 (q) Angophora/Corymbia; (r) Eucalyptus sp.; (s) and (t) E. fraxinoides; (u) Kunzea/Baeckea

Scale bar $-10 \mu \mathrm{m}$ 
Core samples 194, 195, depth 980-1002 mm, age $3400 \mathrm{BP}$

14 grains, 1 unmatched, 7 generically matched, 6 fully matched.

Five Eucalyptus species were identified in samples from 3400 years ago (Figure 6), with one pollen grain each being attributed to Callistemon (Figure 6 e) and Baeckea.

\section{Core sample 202, depth 1006-1009 mm, age $3500 \mathrm{BP}$}

3 grains, 1 unmatched, 1 generically matched, 1 fully matched.

Three grains in total were found, with one thought to be similar to E. fastigata (Figure $6 \mathrm{~g}$ ), one Callistemon and one Kunzea or Baeckea.

Core samples 238-240, depth 1197-1213 mm, age $4300 \mathrm{BP}$

47 grains, 6 unmatched, 19 generically matched, 22 fully matched.

A marked increase in smaller grains was seen from 4300 years ago. Leptospermum (Figure 6 $\mathrm{q}$ and w), Kunzea (Figure $6 \mathrm{r}$ and $\mathrm{x}$ ) and Baeckea (Figure $6 \mathrm{l}$ and p) grain types all appeared more prevalent, suggesting that vegetation composition was different during this time. Eucalyptus fraxinoides (Figure 6 i, m and t) pollen type was abundant. Seven other Eucalyptus grains were identified, as well as Callistemon, Tristania and Tristaniopsis.

\section{Core samples 269-271, depth 1369-1386 mm, age $4700 \mathrm{BP}$}

69 grains, 15 unmatched, 33 generically matched, 21 fully matched.

Eucalyptus fraxinoides (Figure $7 \mathrm{c}$ and $\mathrm{k}$ ) and E. pauciflora (Figure $7 \mathrm{p}$ ) type pollen were the most common seen in samples from 4700 years. Eucalyptus fastigata (Figure 7 a) and E. rubida (Figure 7 r) also had a number of pollen grains identified, while four other Eucalyptus species were found. The number of Callistemon (Figure $7 \mathrm{~g}$ and $\mathrm{m}$ ) pollen grains increased in this time period and many smaller pollen grains from Kunzea (Figure $7 \mathrm{o}$ and $\mathrm{u}$ ), Leptospermum (Figure $7 \mathrm{f}, \mathrm{n}, \mathrm{s}$ and $\mathrm{t}$ ) and Baeckea (Figure $7 \mathrm{v}$ ) were seen.

\section{Core sample 274, depth 1399-1404 mm, age $4800 \mathrm{BP}$}

15 grains, 2 unmatched, 9 generically matched, 4 fully matched.

Eucalyptus fraxinoides type grains (Figure $7 \mathrm{y}$, overleaf) were most prevalent and five other Eucalyptus species were found in small numbers. Smaller grains from Kunzea (Figure 7 aa), Baeckea (Figure $7 \mathrm{z}$ ) and Leptospermum (Figure ab) were found in smaller numbers.

\section{Core samples 290, 291, depth 1494-1505 mm, age $5000 \mathrm{BP}$}

42 grains, 9 unmatched, 18 generically matched, 15 fully matched.

Four Eucalyptus species, E. fraxinoides (Figure 8 h), E. panciflora (Figure 8 a), E. fastigata (Figure $8 \mathrm{c}$ ) and $E$. rubida had similar numbers of pollen types identified. One tetraporate grain (Figure $8 \mathrm{j}$ ) was found and attributed to Eucalyptus. The most common pollen grains were small syncolpate grains of Kunzea (Figure $8 \mathrm{~m}$ ) and Baeckea (Figure $8 \mathrm{n}$ ), while one grain each of Tristania (Figure $8 \mathrm{~g}$ ) and Leptospermum was found.

\section{Core samples 344-346, depth 1796-1814 mm, age 8500 BP}

19 grains, 2 unmatched, 15 generically matched, 2 fully matched.

Grains from Eucalyptus species were the only pollen identified in this period, Eucalyptus fraxinoides (Figure $8 \mathrm{v}$ ), E. pauciflora (Figure $8 \mathrm{~s}$ ) and E. fastigata (Figure $8 \mathrm{o}$ ) being the most abundant, with three other species also being recognised. 


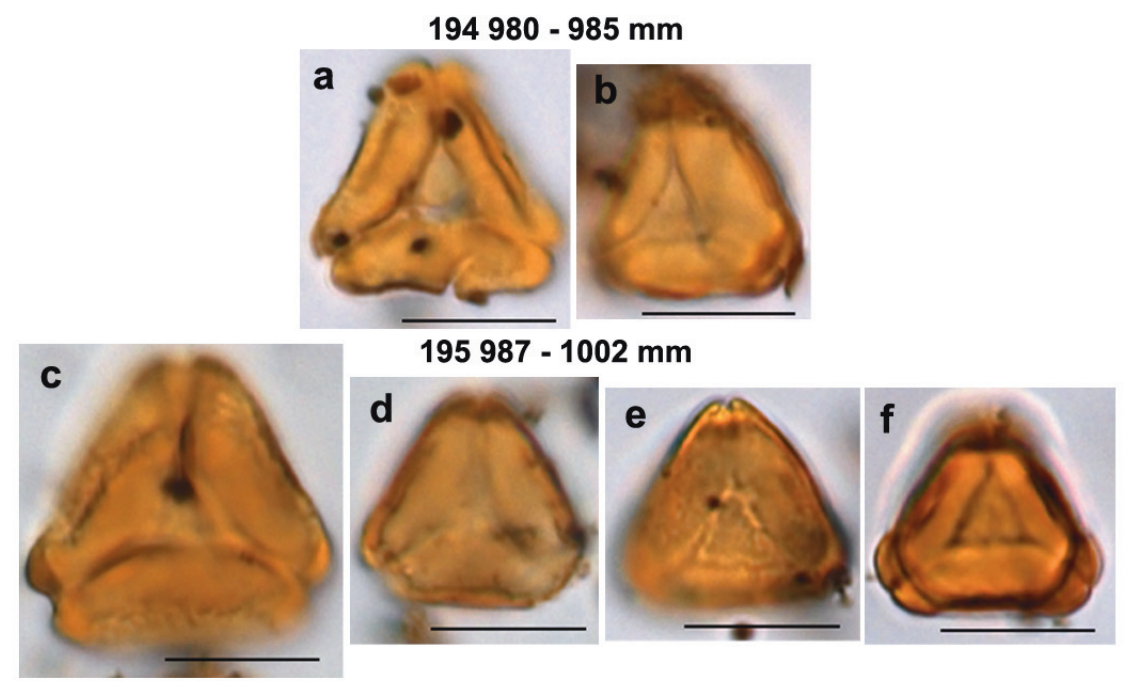

$2021006-1009 \mathrm{~mm}$

g
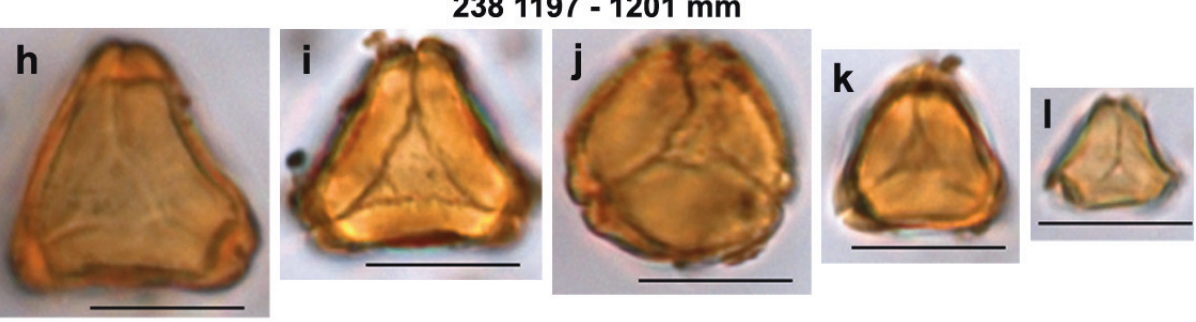

$2391202-1207 \mathrm{~mm}$
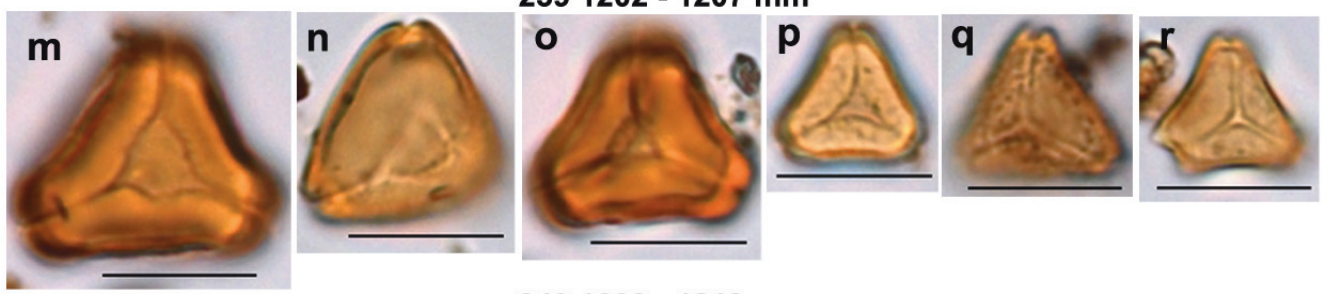

$2401208-1213 \mathrm{~mm}$

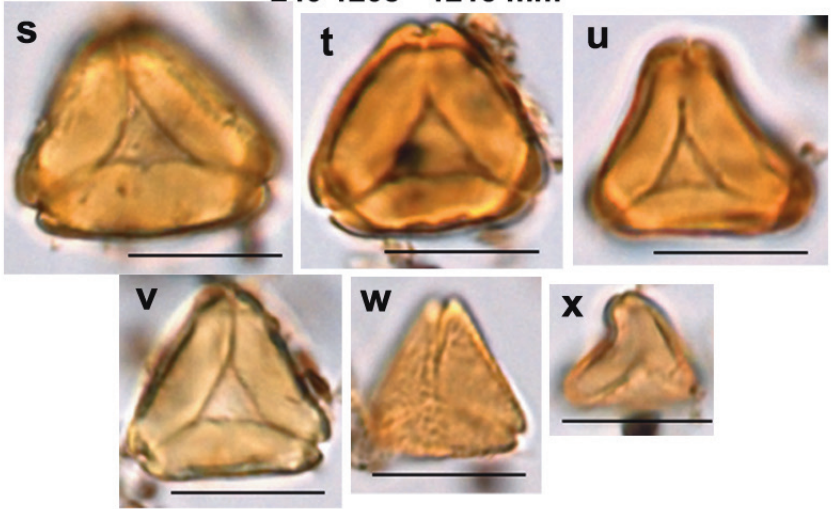

Figure 6. Examples of fossil pollen types from Bega Swamp core sections 194, 195, 202 and 238-240 with related core depth. 194 (a) E. pauciflora; (b) E. fraxinoides; 195 (c) E. stellulata; (d) E. rubida; (e) Callistemon; (f) E. smithii; 202 (g) E. fastigata; 238 (h) E. viminalis; (i) E. fraxinoides; (j) E. dalrympleana; (k) E. radiata/rubida; (l) Baeckea; 239 (m) E. fraxinoides; (n) E. viminalis; (0) E. rubida; (p) Baeckea; (q) Leptospermum; (r) Kunzea; 240 (s) E. stellulata; (t) E. fastigata; (u) and (v) E. fraxinoides; (w) Leptospermum; (x) Baeckea/Kunzea

Scale bar $-10 \mu \mathrm{m}$ 

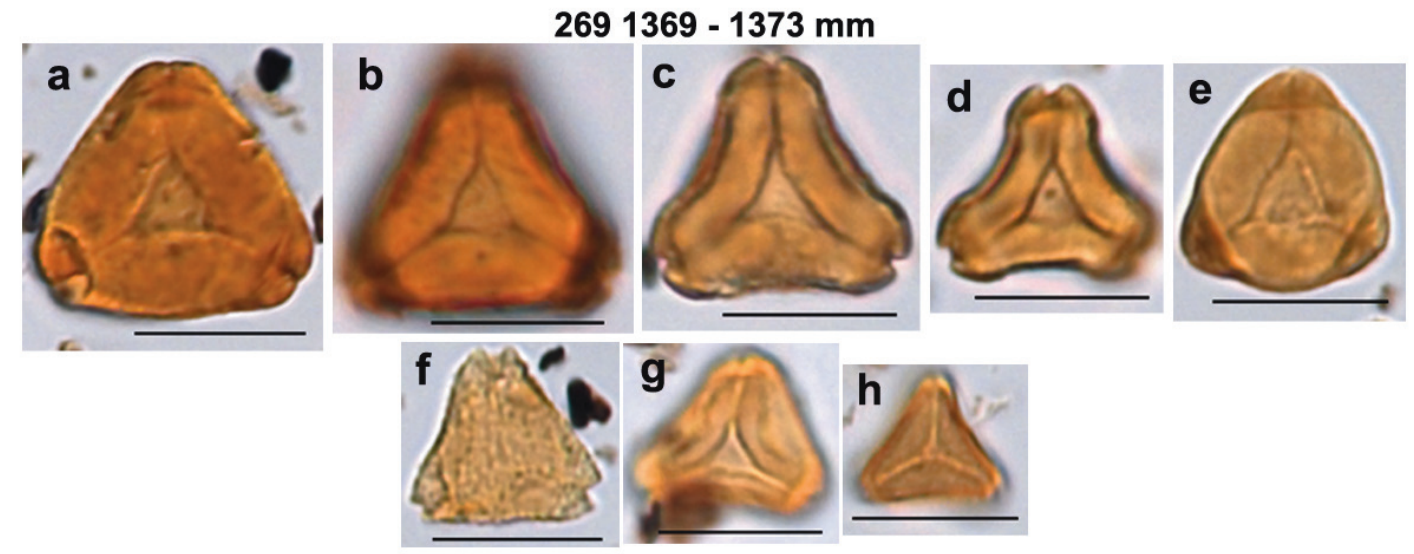

$2701375-1380 \mathrm{~mm}$
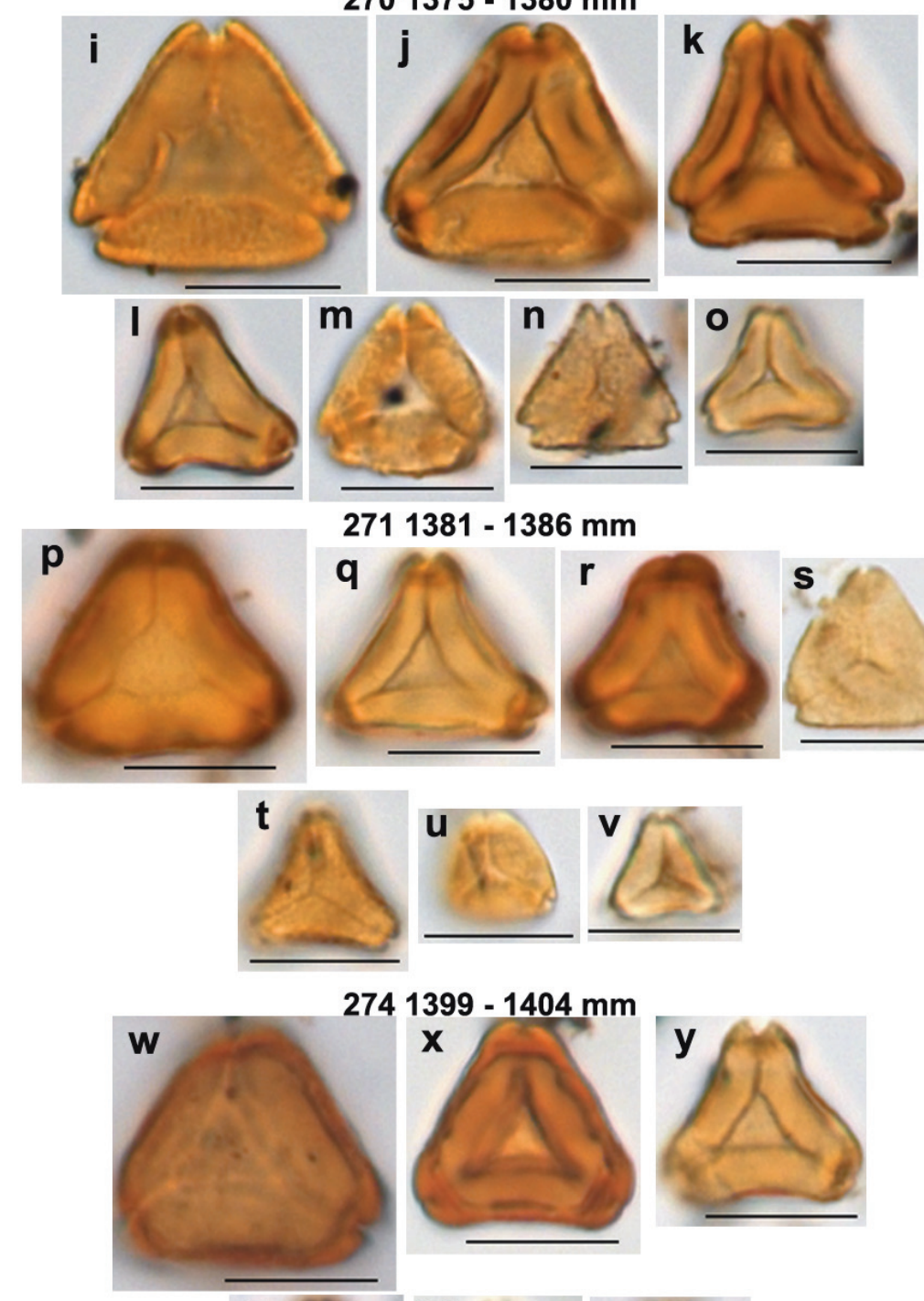

2711381 - $1386 \mathrm{~mm}$
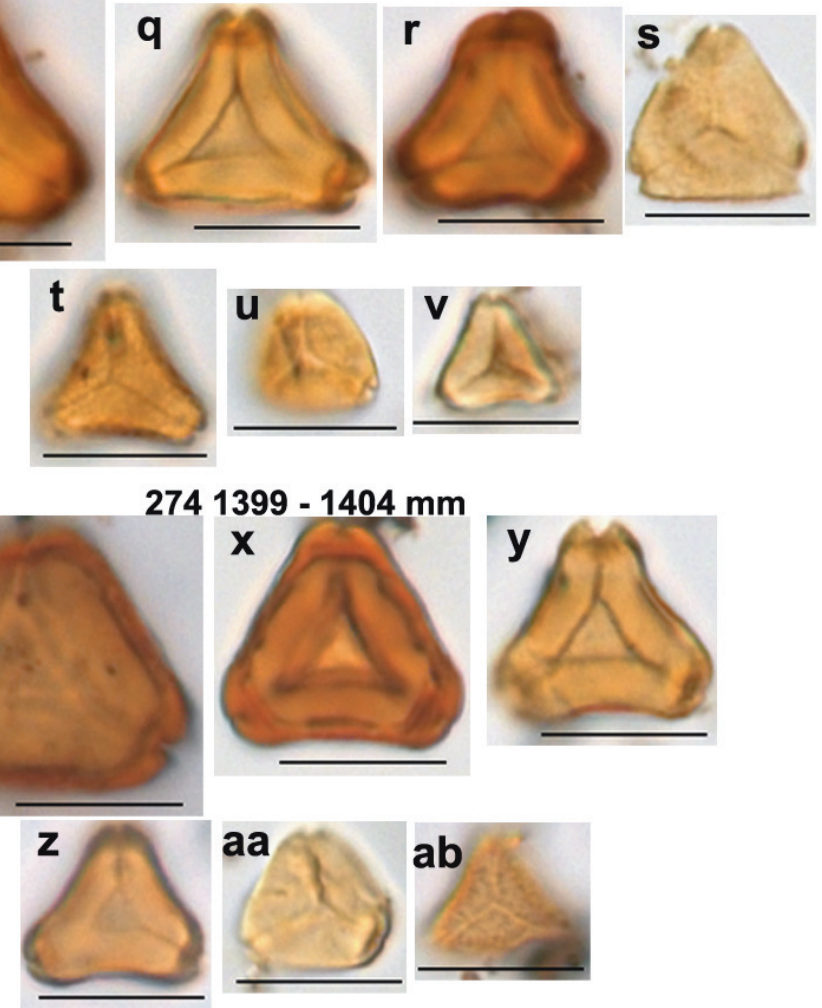

Figure 7. Examples of fossil pollen types from Bega Swamp core sections 269-271 and 274 with related core depth. 269 (a) $E$. fastigata; (b) E. dalrympleana; (c) E. fraxinoides/pauciflora; (d) E. fastigata; (e) E. smithii; (f) Leptospermum; (g) Callistemon; (h) Kunzea/Baeckea; 270 (i) E. stellulata; (j) E. viminalis; (k) E. fraxinoides; (I) Kunzea; (m) Callistemon; (n) Leptospermum; (0) Kunzea; 271 (p) \& (q) E. pauciflora; (r) E. smithii; (s) Leptospermum; (t) Leptospermum; (u) Kunzea; (v) Baeckea; 274 (w) E. viminalis; (x) E. fastigata; (y) E. fraxinoides; (z) Baeckea; (aа) Kunzea; (ab) Leptospermum

Scale bar $-10 \mu \mathrm{m}$ 


\section{Core sample 374, depth 1971-1975 mm, age $8800 \mathrm{BP}$}

12 grains, 4 unmatched, 5 generically matched, 3 fully matched.

Around half the grains identified in this section were small syncolpate grains of Kunzea (Figure $8 \mathrm{z}$ ), Baeckea and Leptospermum (Figure 8 aa, overleaf). Three Eucalyptus species were identified, as was one Callistemon (Figure 8 y) grain.

\section{Core samples 440-442, depth 2199-2213 mm, age 10,900 BP}

33 grains, 4 unmatched, 24 generically matched, 5 fully matched.

Six Eucalyptus species were found, E. pauciflora (Figure 9 i, overleaf) and E. fraxinoides (Figure $9 \mathrm{j}$ ) types being the most common. A tetraporate pollen grain with an apocolpial island (Figure $9 \mathrm{~b}$ ) was found and appeared similar to extant tetraporate grains of Callistemon (Figure $3 \mathrm{f}$ ). Smaller syncolpate grains were less abundant.

\section{Core samples 498-500, depth 2497-2511 mm, age 12,500 BP}

26 grains, 6 unmatched, 16 generically matched, 4 fully matched.

Eucalyptus viminalis (Figure $9 \mathrm{q}$ ) and E. fastigata (Figure $9 \mathrm{n}$ ) grains were identified as the most common grains from the oldest samples analysed. Eucalyptus type pollen was more diverse in this section, with five other pollen types being identified. The number for Kunzea (Figure $9 \mathrm{u}$ ) and Baeckea (Figure 9 w) pollen was slightly higher, and one grain each of Callistemon (Figure $9 \mathrm{z}$ ) and Leptospermum was found.

\section{Validating fossil data}

Images of fossil pollen were shown to Geoff Hope to establish which pollen types represented Myrtaceae groups from the Hope et al. (2000) pollen diagram (Figure 2). Eucalyptus type 1 grains were best illustrated by Figure $5 \mathrm{k}$. Eucalyptus type 2 pollen were similar to Figure $4 \mathrm{a}$ and j. Eucalyptus type 3 pollen was similar to Figure 5 n. Eucalyptus type 4 was most like Figure $4 \mathrm{~b}$ and Eucalyptus type 5 like Figure $4 \mathrm{f}$. The smaller pollen grains were attributed to Kunzea (Figure 5 e), Baeckea (Figure $5 \mathrm{f}$ ) and Leptospermum (Figure $6 \mathrm{q}$ ). When comparing the Hope et al. (2000) Eucalyptus types to extant grains it was seen that Eucalyptus 1 looked similar to E. pauciflora (Figure 3 o). Eucalyptus 2 grains, which were thought to belong to E. pauciflora, looked similar to E. fraxinoides (Figure 3 n), E. pauciflora (Figure 3 o) and E. fastigata (Figure $3 \mathrm{~m}$ ). Eucalyptus type 3 grains appeared most like E. dalrympleana (Figure $3 \mathrm{k}$ ), E. radiata (Figure $3 \mathrm{p}$ ) and E. smithii (Figure 3 s). Eucalyptus type 4 was very similar to E. viminalis (Figure $3 \mathrm{u}$ ), as was Eucalyptus type 5.

\section{Discussion}

The vegetation history of Bega Swamp interpreted from pollen diagrams by Hope et al. (2000) observes a transition from shrubby daisy-grass steppe to a low eucalypt (presumed snowgum) woodland by about 11,800 BP and then a phase of herbfield development. Eucalypt forest appeared abruptly around $9400 \mathrm{BP}$ and increased in diversity. Changes in eucalypt dominance occurred around 7000 and $4000 \mathrm{BP}$, which may represent shifts to the E. fastigatalE. dalrympleana forest of the present day. The centre of a possible 'wet phase' happened between $6000 \mathrm{BP}$ and $3300 \mathrm{BP}$. The present study searched selected core samples for Myrtaceae pollen which could correlate with this vegetation history interpretation. It was found that younger core samples contained higher concentrations and a wider variety of Eucalyptus type pollen than older sections. The dominant pollen type fluctuated through the core and this was also stated by Hope et al. (2004), who suggested that this may represent quite minor transitions across environmental limits or even autogenic processes that are not driven by external changes. 

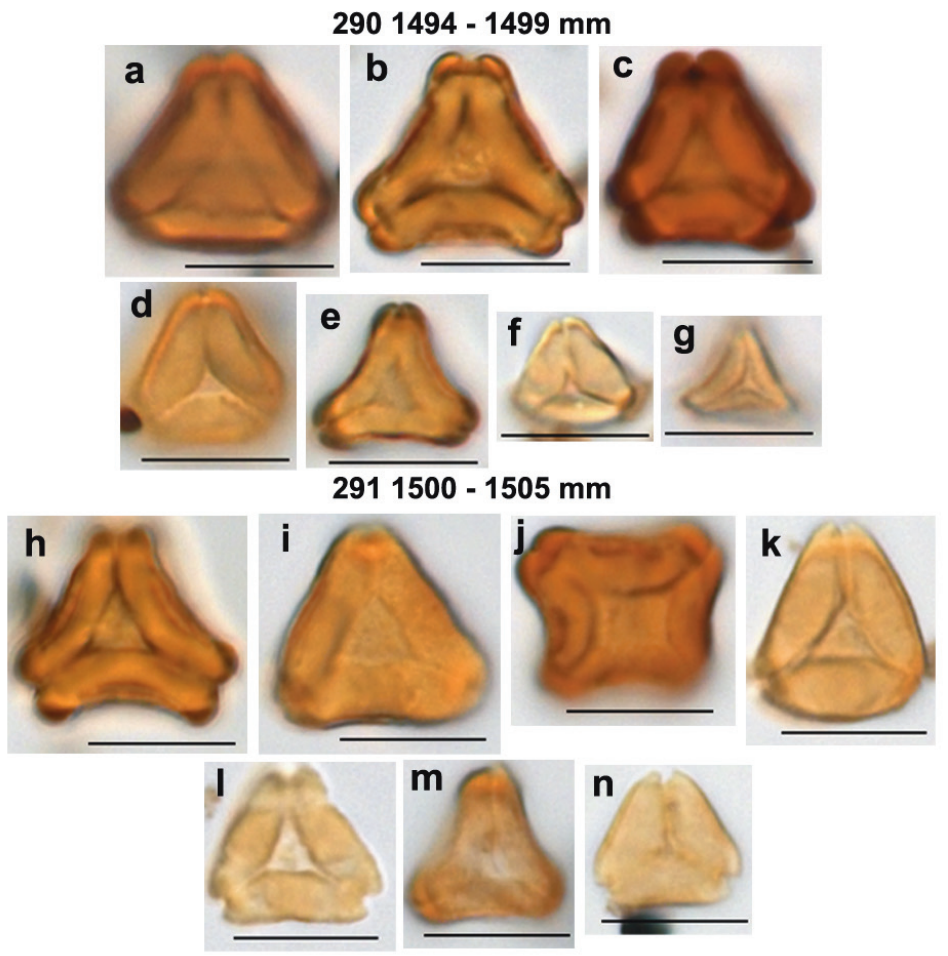

$3441796-1801 \mathrm{~mm}$

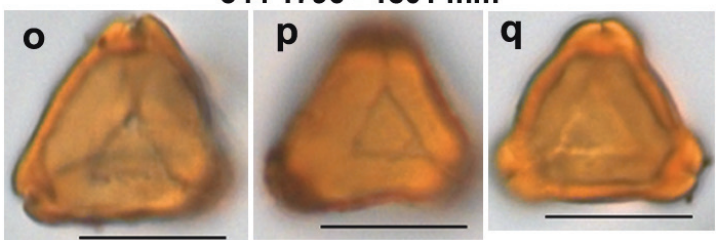

$3451803-1808 \mathrm{~mm}$
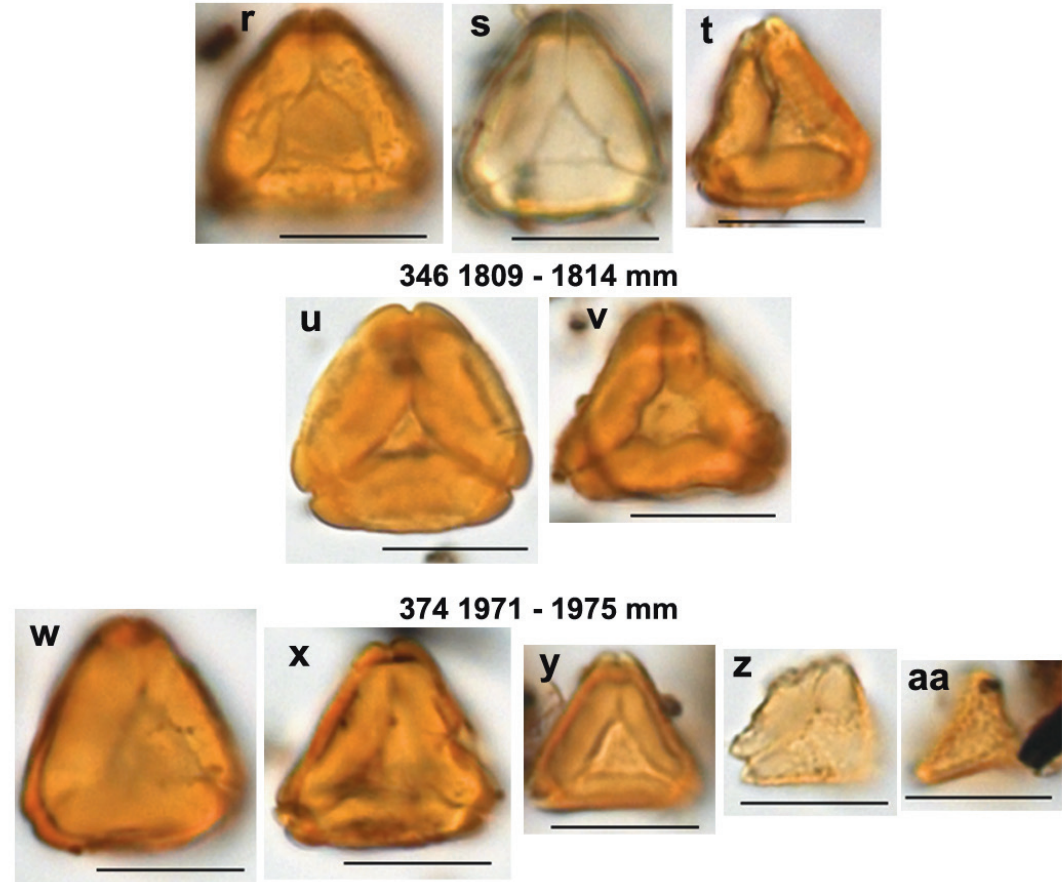

Figure 8. Examples of fossil pollen types from Bega Swamp core sections 290, 291, 344-346 and 374 with related core depth. 290 (a) E. pauciflora; (b) E. fraxinoides; (c) E. fastigata; (d) and (e) Kunzea; (f) Baeckea; (g) Baeckea/Kunzea; 291 (h) E. pauciflora; (i) E. dalrympleana; (j) Tetraporate Eucalyptus; (k) E. smithii; (I) E. pauciflora; (m) Kunzea; (n) Baeckea; 344 (o) E. fastigata; (p) E. viminalis; (q) E. rubida; 345 (r) E. fastigata; (s) E. pauciflora; (t) E. fastigata; 346 (u) E. stellulata; (v) E. fraxinoides; 374 (w) E. fastigata; (x) E. pauciflora; (y) Callistemon; (z) Kunzea/Leptospermum; (aа) Leptospermum Scale bar - $10 \mu \mathrm{m}$ 

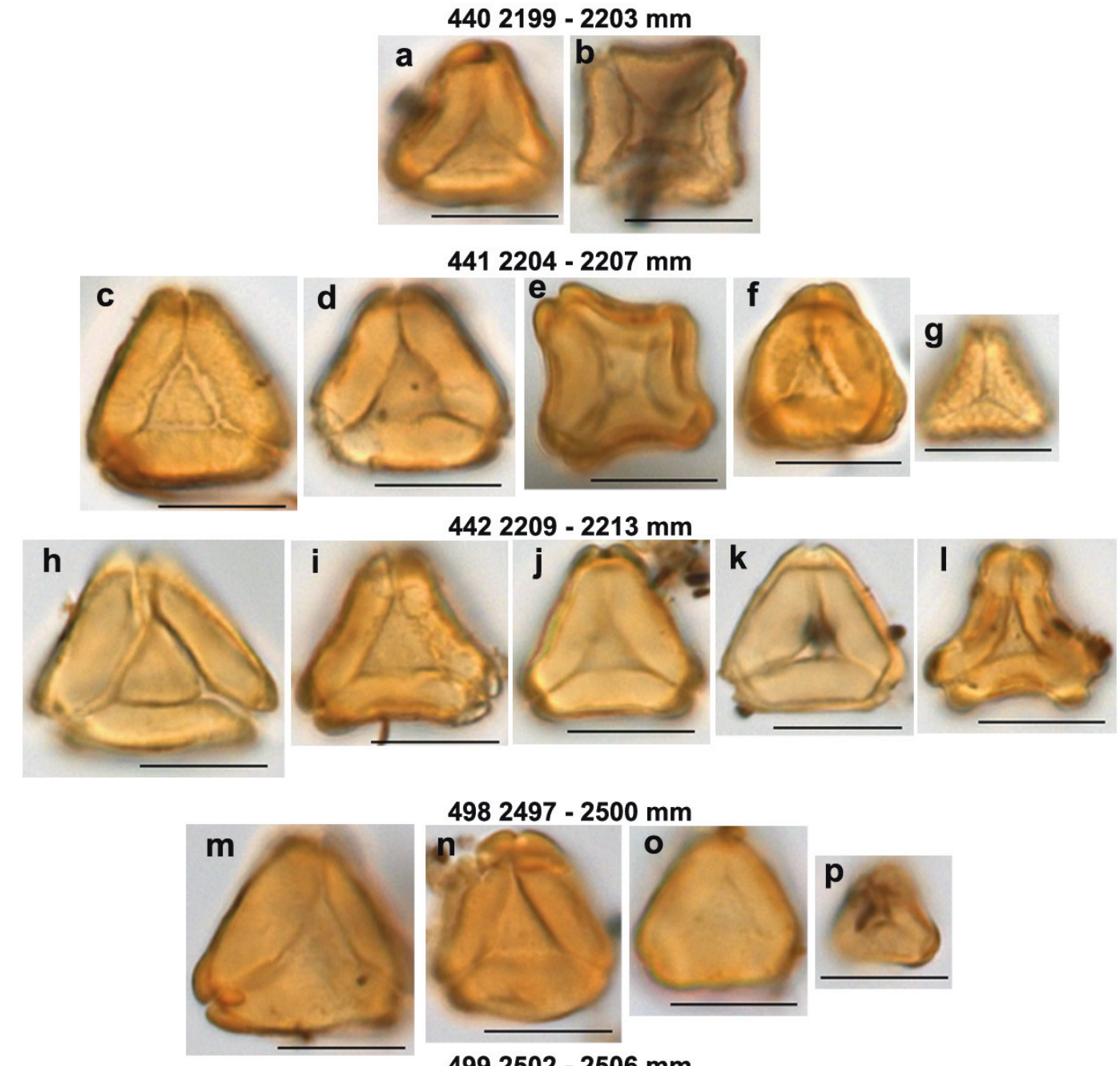

$4982497-2500 \mathrm{~mm}$
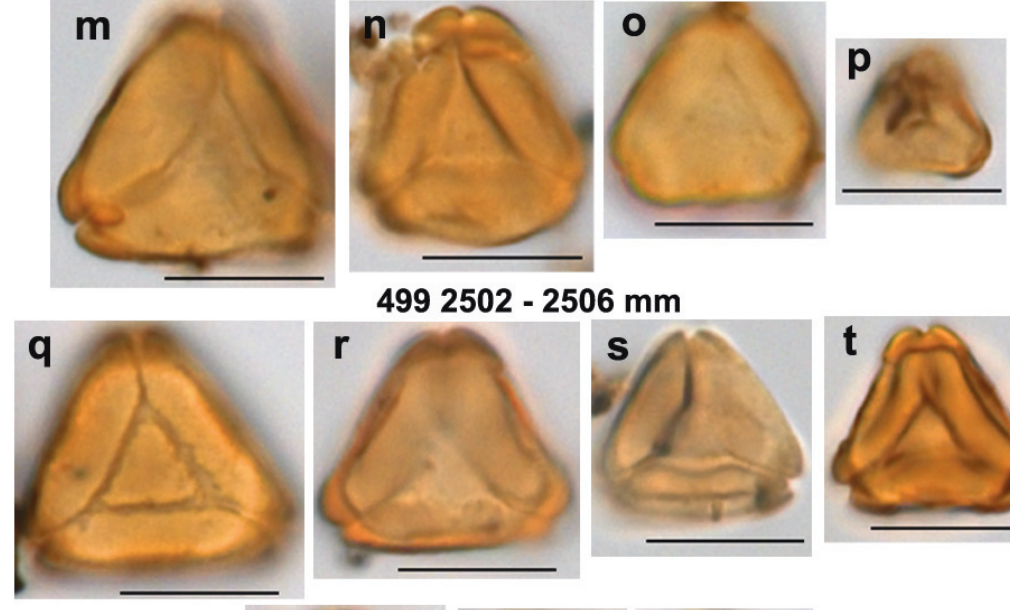

$4992502-2506 \mathrm{~mm}$
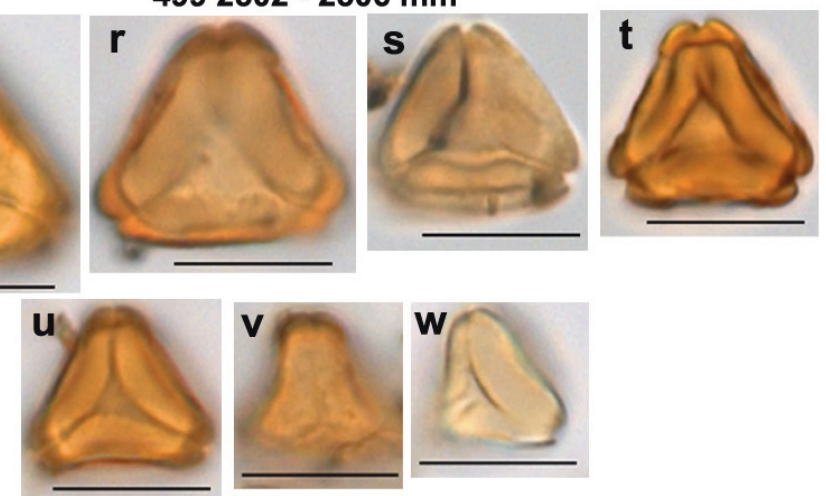

$5002507-2511 \mathrm{~mm}$
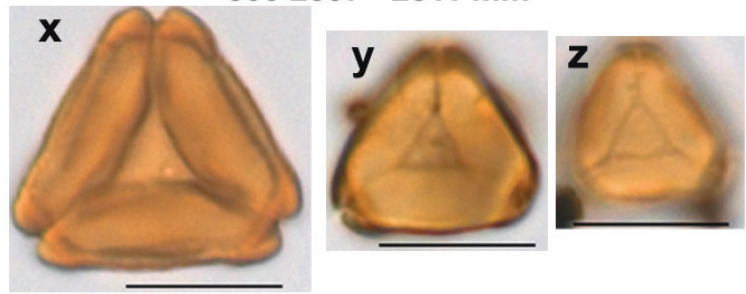

Figure 9. Examples of fossil pollen types from Bega Swamp core sections 440-442 and 498-500 with related core depth. 440 (a) E. rubida; (b) Tetraporate Callistemon; 441 (c) E. viminalis; (d) E. fastigata; (e) Tetraporate Eucalyptus; (f) E. rubida; (g) Leptospermum; 442 (h) and (i) E. pauciflora; (j) E. fraxinoides; (k) E. pauciflora; (l) E. fraxinoides; 498 (m) E. stellulata; (n) E. fastigata; (0) E. fraxinoides; (p) Baeckea/Kunzea; 499 (q) E. viminalis; (r) E. fastigata; (s) Eucalyptus sp.; (t) E. fraxinoides; (u) Baeckea/Kunzea; (v) Kunzea; (w) Baeckea; 500 (x) E. fastigata; (y) E. pauciflora; (z) Callistemon

Scale bar $-10 \mu \mathrm{m}$ 
Eucalyptus pauciflora (snowgum) pollen was found in all but two of the sections sampled and in higher concentrations in older and younger samples, with lower values in between. However, E. fraxinoides (white ash) type pollen, which looks very similar to E. pauciflora but is smaller, was found in high concentrations when the larger $E$. pauciflora type was not as abundant (4300 to $4700 \mathrm{BP}$ ). If these fossil grains are indeed E. fraxinoides, it would suggest a wet, tall eucalypt forest present at Bega Swamp during this time. E. dalrympleana, E. rubida, E. smithii and E. viminalis pollen types all began showing higher concentrations in mid-core sections, starting around $5000 \mathrm{BP}$, matching suggestions that dominant present-day vegetation emerged somewhere between $6000 \mathrm{BP}$ and 3300 BP. Eucalyptus fastigata, however, was found in high concentrations in the oldest core samples, differing from previous pollen studies, suggesting that components of a tall eucalypt forest have existed in the Bega Swamp area for longer than has been assumed.

Comparing the suggested eucalypt groups of Hope et al. (2000) with extant pollen presented problems with the interpretation. Nine extant Eucalyptus species were used as reference material in the present study, which contrasted with Hope et al. (2000) who had five distinct eucalypt pollen groups. While the idea of having five groups would concur with the morphological and ecological groups that occur in the Bega Swamp area (i.e. snowgum, ashes, peppermints etc) and create a neat vegetation transition history as shown in the pollen diagram (Figure 2), the extant pollen morphology did not give full support to the morphological eucalypt pollen groups created by Hope et al. (2000). Eucalypt pollen types 2, 3 and 5 have similarities with extant Eucalyptus pollen across multiple morphological groups - for instance, eucalypt group 2 pollen could belong to the snowgums or ashes, and eucalypt type 3 could belong to ashes or peppermints. To create a vegetation history based on the occurrence of various eucalypt pollen type groups would thus seem implausible.

There have been previous attempts to find distinctive Eucalyptus/Myrtaceae pollen groups (Dodson 1974; Chalson and Martin 1995; Pickett and Newsome 1997). Dodson (1974) identified four types of Eucalyptus pollen from Lake Leake in South Australia and related these pollen types to eucalypt groups comprising 11 extant Eucalyptus species, although how this was done is not exactly clear as the results are published as an appendix. Chalson and Martin (1995) created the characters used in this study and worked only on extant Myrtaceae pollen of the Blue Mountains, finding that all but two taxa could be sorted to a species level. This study showed that there is the ability to separate Myrtaceae pollen to a species level if a wide range of genera and a low number of species from each genus is selected. Pickett and Newsome (1997) used nine Eucalyptus species and fossils from a Holocene swamp at Walpole, Western Australia, finding that extant species could be differentiated to pollen types with some confidence so long as suites of morphological characters, rather than single characters, were used, and that much of the fossil pollen could be allocated to a pollen type if the necessary features were preserved in the pollen grain. However, they also stated that 'a basic pre-requisite is that the area under study has a relatively small number of Eucalyptus species and that these can be separated to a satisfactory extent, on the basis of pollen morphology' (Pickett and Newsome 1997:203). This study also showed that when a small number of known taxa is used as a pollen reference, comparisons with fossil pollen can be more confidently made as there is likely to have been minimal floral composition change during the Holocene and known pollen synapomorphies can be discounted. However, it was not Eucalyptus pollen, but other representatives of the Myrtaceae family that best illustrated this concept.

Sections sampled between 4300 and 5000 BP showed a dramatic increase in the number of smaller syncolpate pollen grains found, representing the wet phase that has been suggested by previous studies (Hope et al. 2000; Donders et al. 2007). While much focus at Bega Swamp has been on what type of Eucalyptus was present throughout the Holocene, little has been mentioned about the smaller Myrtaceae pollen grains present in the core, which may be more indicative and less difficult to interpret than the various Eucalyptus species. The smallest 
of these grains most likely belongs to Tristania neriifolia (water gum), which occurs along rocky creek beds and banks on sandstone. The presence of this grain in core sections suggests that there was running water at or into Bega Swamp at various stages. Pollen grains sized 10$15 \mu \mathrm{m}$ that were psilate and syncolpate most likely came from the genera Baeckea and Kunzea. Differentiating between the grains of these two genera is not easy, so most fossil grains with these characters were assigned to a combined genera type. However, they are both myrtaceous shrubs that occur in bogs and smaller heathland communities and the presence of these pollen grains suggests a more open vegetation type community. The quantity of Eucalyptus pollen types was lower in sections where BaeckealKunzea and Leptospermum pollen grains show a marked increase. While this could be interpreted as a reduction in the area of the surrounding tree forest community during these phases, it could be attributed alternatively to pollen filtration caused by shrub cover. Hope (1968) showed from traps in Wilson's Promontory that shrub cover intercepts pollen from nearby communities, which is then presumably destroyed by sunlight. This was also demonstrated by Tauber (1967) in shrubland surrounding a pond in Denmark. This suggests that while the Bega Swamp bog area may have been dominated by an open heathland community during this time, the surrounding vegetation would most likely have remained a eucalypt forest type.

Pollen grains sized $10-15 \mu \mathrm{m}$ that were granulate or scabrate and syncolpate closely matched extant grains of Leptospermum species. The presence of these grains also suggests a more open heathland type community. It can also be noted from the Bega Swamp pollen diagram (Figure 2) that there is a decrease in charcoal found around the same time of the Leptospermum and BaeckealKunzea increase. Bickford and Gell (2005) suggested that the presence of Leptospermum at around 6500 BP in a core from the Fleurieu Peninsula, South Australia, combined with the presence of Cyperaceae, Allocasuarina (paludosa or robusta) and Banksia marginata represented a wet-heath community. This concurs with the previous studies on Bega Swamp that suggest a mid-Holocene wet phase, characterised by expansion of wet heath and ferns, starting around 7500 BP (Donders et al. 2007). Bickford and Gell (2005) also suggested that the dramatic increase in Leptospermum pollen could be accounted for in part by the reduction of Acacia present in the wetlands and surrounding vegetation following clearance and the cessation of regular burning. Other research has shown that Leptospermum benefits from a lack of fire (Bennet 1994; Johnson 2001), while it has also been suggested that fire benefits Leptospermum, which is tolerant of high-intensity fires (Morrison and Renwick 2000; Bond et al. 2004). This result suggests that Leptospermum and Kunzeal Baeckea pollen are better vegetation and climate indicators than separating Eucalyptus pollen into different sub-genera or species types.

Using size as a sorting characteristic did not prove efficient when using the Lucid key. Entering morphological characteristics of fossil pollen into the Lucid key often resulted in close matches with extant Myrtaceae pollen, but when measurements were combined with morphology no matches were commonly encountered. This may be explained by the use of different mounting media. The Bega Swamp samples were mounted in silicone oil; extant samples in a variety of substrates such as syn-matrix and glycerine, and differing sizes in relation to mounting media and acetolysis treatment has been noted before (Deuse 1960; Drugg 1962). To rely on size as a characteristic when searching for possible fossil-extant matches thus involves greater ranges depending on how many mounting substrates have been used, and creates less certainty.

\section{Conclusion}

Eucalyptus pollen morphology of the extant taxa did not consistently match morphological or ecological groups. Pollen grains of the symphomyrtus group did not look the same $(E$. 
dalrympleana, E. rubida, E. smithii and E. viminalis), but similarities could be found within the group, such as the presence of a large apocolpial island (E. rubida and E. viminalis). Another important pollen morphology similarity in Eucalyptus was that seen between E. pauciflora (snowgum) and E. fraxinoides (white ash).

This raises doubts about using Eucalyptus pollen types when interpreting past vegetation and climatic conditions. On the other hand, Myrtaceae genera such as Leptospermum, Kunzea, Baeckea, Melaleuca (Callistemon), AngophoralCorymbia, Tristaniopsis and Tristania are more easily identifiable, especially when known pollen synapomorphies do not occur in the area. While it would be foolish to announce with complete certainty that fossil pollen grains match extant pollen grains, sentiments that have been expressed before by Joosten and de Klerk (2002), it is not unreasonable to suggest that pollen grains from the Holocene that display similar characteristics as extant pollen are most likely the same genus, or more safely, tribe within the Myrtaceae family. The confidence in comparing fossil and extant pollen increases when an extant taxa sample size is small and the extant taxa have distinct pollen characteristic suites such as observed in Leptospermum, which has small, granulate/scabrate patterned grains, Kunzea, which is syncolpate and less patterned than Leptospermum, or Callistemon, which always has a polar island, and Tristania, which has very small pollen grains (less than $8 \mu \mathrm{m}$ ).

\section{Acknowledgements}

The author would like to thank Gillian Brown and Andrew Drinnan from the School of Botany, University Melbourne, and Ian Thomas from the School of Land and Environment for loaning slides from the Kathleen Pike collection that were used as reference for extant Myrtaceae pollen. Finally, Geoff Hope provided his entire Bega Swamp reference material, including past articles, correspondence, maps and images. Two anonymous reviewers provided useful comments on the manuscript.

\section{References}

Barth, O.M. and A.F. Barbosa 1973. Catalogo sistematico do polens das plantas arborea do Brasil meridional XV Myrtaceae. Memorias do Instituto Oswaldo Cruz 70:467-497.

Bennet, L.T. 1994. The expansion of Leptospermum laevigatum on the Yanakie Isthmus, Wilson's Promontory, under changes in the burning and grazing regimes. Australian Journal of Botany 42(5):555-564.

Bickford, S. and P. Gell 2005. Holocene vegetation change, Aboriginal wetland use and the impact of European settlement on the Fleurieu Peninsula, South Australia. Holocene 15(2):200-215.

Bond, W.J., K.J.M. Dickinson and A.F. Mark 2004. What limits the spread of fire-dependent vegetation? Evidence from geographic variation of serotiny in a New Zealand shrub. Global Ecology and Biogeography 13(2):115-127.

Chalson, J.M. and H.A. Martin 1995. The Pollen Morphology of Some Co-occurring Species of the Family Myrtaceae from the Sydney Region. Proceedings of the Linnean Society of New South Wales 115:163-191.

Churchill, D.M. 1968. Distribution and Prehistory of Eucalyptus diversicolor F Muell E Marginata Donn Ex Sm and E Calophylla R Br in Relation to Rainfall. Australian Journal of Botany 16(1):125-151.

Deuse, K.F.P. 1960. Size variations in pollen grains with different treatments. Pollen et Spores 2:293-298. 
Dodson, J.R. 1974. Vegetation history and water fluctuations at Lake Leake, south-eastern South Australia. I. 10000 BP to present. Australian Journal of Botany 22(4):719-741.

Donders, T., S. Haberle, G. Hope, F. Wagner and H. Visscher. 2007. Pollen evidence for the transition of the eastern Australian climate system from the post-glacial to the present-day ENSO mode. Quaternary Science Reviews 26(11-12):1621-1637.

Drugg, W.S. 1962. Pollen Morphology of Lennoaceae. American Journal of Botany 49(10):10271032.

Eliseu, S.A. and A.M. Dinis. 2008. Ultrastructure and cytochemistry of Eucalyptus globulus (Myrtaceae) pollen grain. Grana 47:39-51.

Gadek, P.A. and H.A. Martin 1981. Pollen Morphology in the Subtribe Metrosiderinae of the Leptospermoideae (Myrtaceae) and Its Taxonomic Significance. Australian Journal of Botany 29(2):159-184.

Gadek, P.A. and H.A. Martin 1982. Exine Ultrastructure of Myrtaceous Pollen. Australian Journal of Botany 30(1):75-86.

Graham, A. 1980. Morfologia del polen de Eugenia-Myrcia (Myrtaceae) y CombretumTerminalia (Combretaceae) en relacion a su alcance estratigrafico en el Terciario del Caribe. Biotica 5(1):5-14.

Green, D., G. Singh, H. Polach, D. Moss, J. Banks and E. A. Geissler 1988. A fine-resolution palaeoecology and palaeoclimatology from south-eastern Australia. Journal of Ecology 76(3):790-806.

Hope, G. 1968. Pollen studies at Wilson's Promontory. Unpublished M.Sc.. Melbourne: University of Melbourne.

Hope, G. 1995. Robustness and sensitivity of pollen data -A high resolution record from Bega Swamp, New South Wales. Climate Change Retrospect and Prospect; Quantifying the Past to Understand the Future. University of Melbourne November 6-8 1995.

Hope, G., A. Kershaw, S. van der Kaars, S. Xiangjun, P. Liew, L. Heusser, H. Takahara, M. McGlone, N. Miyoshi and P. Moss 2004. History of vegetation and habitat change in the Austral-Asian region. Quaternary International 118-19:103-126.

Hope, G., G. Singh, E. Geissler, L. Glover and D. O'Dea 2000. A Detailed PleistoceneHolocene Vegetation Record from Bega Swamp, southern New South Wales. Quaternary Studies Meeting. Regional analysis of Australian Quaternary Studies: strengths, gaps and future directions. Canberra: Department of Geology, The Australian National University.

Johnson, P.N. 2001. Vegetation recovery after fire on a southern New Zealand peatland. New Zealand Journal of Botany 39(2):251-267.

Joosten, H. and P. de Klerk 2002. What's in a name? Some thoughts on pollen classification, identification, and nomenclature in Quaternary palynology. Review of Palaeobotany and Palynology 122(1-2):29-45.

Martin, H.A. and P.A. Gadek 1988. Identification of Eucalyptus spathulata pollen and its presence in the fossil record. Memoirs of the Association of Australasian Palaeontologists 5:311-327.

McIntyre, D.J. 1963. Pollen Morphology of New Zealand Species of Myrtaceae. Transactions of the Royal Society of New Zealand 2(7):83-107.

Morrison, D.A. and J.A. Renwick 2000. Effects of variation in fire intensity on regeneration of co-occurring species of small trees in the Sydney region. Australian Journal of Botany 48(1):71-79.

Parnell, J. 2003. Pollen of Syzygium (Myrtaceae) from SE Asia, especially Thailand. Blumea 48(2):303-317.

Patel, V.C., J.J. Skvarla and P.H. Raven 1984. Pollen characters in relation to the delimitation of Myrtales. Annals of the Missouri Botanical Garden 71(3):858-969. 
Pickett, E.J. and J.C. Newsome 1997. Eucalyptus (Myrtaceae) pollen and its potential role in investigations of Holocene environments in southwestern Australia. Review of Palaeobotany and Palynology 98(3-4):187-205.

Pike, K.M. 1956. Pollen morphology of Myrtaceae from the south-west Pacific area. Australian Journal of Botany 4:13-53.

Polach, H. and G. Singh 1980. Contemporary $14 \mathrm{C}$ levels and their significance to sedimentary history of Bega Swamp, New South Wales. Radiocarbon 22(2):398-409.

Punt, W., P.P. Hoen, S. Blackmore, S. Nilsson and A. Le Thomas 2007. Glossary of pollen and spore terminology. Review of Palaeobotany and Palynology 143(1-2):1-81.

Tauber, H. 1967. Investigations of the mode of pollen transfer in forested areas. Review of Palaeobotany and Palynology 3:277-286.

Van Wyk, A.E. and I. Dedekind 1985. The genus Eugenia (Myrtaceae) in Southern-Africa: morphology and taxonomic value of pollen. South African Journal of Botany 51(5):371-378.

Wheeler, D., A.R. Chivas and G. Hope 2001. Isotope Stratigraphy of Bega Swamp, Southern NSW. Australasian Quaternary Association meeting, Southcombe Lodge, Port Fairy. 